DOI: $10.17242 / M V v K \_30.03$

\title{
VETÉSI LÚD (Anser fabalis) FAJKEZELÉSI TERV MAGYARORSZÁGON
}

\author{
MANAGEMENT PLAN FOR BEAN GOOSE (Anser fabalis) IN HUNGARY
}

\author{
Faragó Sándor, Musicz László \& Hajas Péter Pál
}

\begin{abstract}
Magyar Vízivad Kutató Csoport, Soproni Egyetem Vadgazdálkodási és Gerinces Állattani Intézet Hungarian Waterfowl Research Group, Institute of Wildlife Management and Vertebrate Zoology, University of Sopron, H-9400 Sopron, Ady Endre u. 5., Hungary
\end{abstract}

\section{A VETÉSI LÚD BIOLÓGIÁJA ÉS ÖKOLÓGIÁJA, A VÉDELMI GYAKORLAT ÉRTÉKELÉSE}

\subsection{BEVEZETÉS}

Az A. f. fabalis-t példányszámának csökkenő trendje és 85000 (-100 000) pd-os állománya alapján már HUYSKENS (1999) a globálisan veszélyeztetett kategóriájába sorolta (Hasonló státusszal, mint a vörösnyakú ludat és a kis liliket). Legfontosabb veszélyeztető tényezőnek a skandináviai hosszú vadászidényt és a nagy terítékeket tartotta. Az A. f. rossicus alfaj állománya növekszik, ami azt mutatja, hogy nincs lényeges állománycsökkentő tényező sem a fészkelö, sem a telelőterületeken. Az egységes vetési lúd fajra megállapított védelmi intézkedések értelmében a vetési lúd a Berni Egyezmény II. Mellékletében, a Bonni Egyezmény II. Függelékében, valamint az EU Madárvédelmi Irányelvek II/1 Függelékében szerepel. Állomány-növekedésének egyedül károkozása szabhat korlátot. A bölcs hasznosítás alapelvein nyugvó vadászattal még növekedése is fenntartható. Bár napjainkban vadászható vadlúdfajunk, vészes állománycsökkenése intézkedéseket követelhet a jövőben. Vadászati rendeletek korábban csak az idény hosszával korlátozták hasznosításának mértékét. Az idény mindig október 1.-ével kezdődött, s hol január 15.-ig, hol január 31.-ig tartott. Az érvényes FVM. rendelet szerint október 1. - január 31. között vadászható. 1993-ban első alkalommal vezettek be terítékkorlátozást a faj védelme érdekében, vadászonként legfeljebb naponta 4 vetési lúd ejthető el. Ma az elejthető napi egyedszám 6 pld. A megfogyott létszámú fajt „,nagyvadként” kezelve kell hasznosítani. Vadgazdálkodási értéke $20000 \mathrm{Ft}$.

\section{2. ÖKOLÓGIA}

\subsection{1. Élőhelyi feltételek}

Mind a tundrán, mind a tajgán fészkel. Láthattuk, hogy egyes fajok/alfajok az egyik, mások a másik élőhely-típushoz kötődnek. Közös bennük, az hogy a fészkelőhelyek mindig nedves területekhez kapcsolódnak: vagy a folyók mocsárvidékeinek vizeihez (tundra), vagy a kisebb folyók, patakok által létrehozott mocsaras mellékágakhoz és nagyobb, erdővel körülvett lápokhoz (tajga). Telelőterületein elöszeretettel keresi fel a mezőgazdasági kultúrákat. A Fertő-tónál végzett vizsgálatok szerint (FARAGÓ, 1994) a vetési lúd éjszakázó- és táplálkozó területei között 60-80, olykor 100 km-es távolság is lehet, ami tulajdonképpen megegyezik a 
Kisalföld területhatáraival. A kirepülés távolsága függ a táplálkozó helyek táplálékkínálatától. Ha közel vannak gazdag kínálatú táplálkozó-területek, akkor a libák a hajnali kihúzás után a délelött folyamán visszarepülnek a tóra, ott isznak és pihennek, majd kora délután ismét kihúznak táplálkozni és napnyugta után térnek meg éjszakázni. Ha csak nagyobb távolságra vannak elérhető táplálkozó területek, akkor a napközbeni visszahúzás elmarad. Abban az esetben, ha hideg időszakban, nagy távolságban találnak a libák táplálékot (pl. kukorica tarlót) az is előfordulhat, hogy éjszakázni sem térnek vissza a tóra. Ez esetben vízszükségletüket a hó csipegetésével fedezik, biztonságérzetüket pedig a nagy táblák közepére való településsel fokozzák. A Fertőről kihúzó libák az idézett vizsgálatok alapján táplálkozó-helyként elsősorban a gabonavetéseket részesítették előnyben (41-63\%), ezt követte a kukorica tarló (25-34\%), a repce (6-11\%), majd a szántások, a cukorrépa- és napraforgó-tarlók, illetve a lucerna. Egy-egy területen általában kétféle élőhelyet (41\%) használtak a libák, jelentős volt a háromféle élőhelyet választók aránya ( $24 \%)$ is, míg egyféle élőhelyet a területek $32 \%$-ában, négyfélét pedig a területek 3\%-ában használtak (FARAGÓ, 1994).

Magyarországi vizsgálatok szerint (FARAGÓ, 2006b; 2011c) a vetési lúd kora őszi időszakban az állandó édesvizü és szikes tavakat, valamint a folyókat választja élőhelyéül. Az őszi időszakban - a nagyobb tömegek megérkezésekor - az említettek mellett a halastavak és víztározók szerepe is jelentős, s ez így marad a tél és a tavasz folyamán is. A teljes szezont tekintve a víztározók, az állandó vizű szikes tavak és a halastavak a faj leginkább preferált élöhelyei (1. táblázat).

1. táblázat: A vetési lúd aspektusonkénti és éves élőhely-választása IVLEV-indexek alapján (FARAGÓ, 2006b)

Table 1: Habitat preference of Bean Goose based on the Ivlev-indices (FARAGÓ, 2006b)

\begin{tabular}{|l|c|c|c|c|c|}
\hline \multicolumn{1}{|c|}{ ANSFAB } & $\begin{array}{c}\text { Kora ösz - } \\
\text { Early autumn }\end{array}$ & $\begin{array}{c}\text { Ősz - } \\
\text { Autumn }\end{array}$ & $\begin{array}{c}\text { Tél - } \\
\text { Winter }\end{array}$ & $\begin{array}{c}\text { Tavasz - } \\
\text { Spring }\end{array}$ & $\begin{array}{c}\text { Szezon - } \\
\text { Season }\end{array}$ \\
\hline Folyó - River & 0,5 & $-0,1$ & 0,0 & 0,1 & 0,0 \\
\hline $\begin{array}{l}\text { Állandó édesvizü tó - } \\
\text { Freshwater lake }\end{array}$ & 0,6 & 0,3 & $-0,2$ & $-0,1$ & 0,0 \\
\hline $\begin{array}{l}\text { Állandó szikes tó - } \\
\text { Saline lake, permanent }\end{array}$ & 0,5 & 0,7 & 0,8 & 0,8 & 0,7 \\
\hline $\begin{array}{l}\text { Idöszakos szikes tó - } \\
\text { Saline lake, seasonal } \\
\text { intermittent }\end{array}$ & $-1,0$ & $-0,8$ & $-0,9$ & 0,0 & $-0,8$ \\
\hline $\begin{array}{l}\text { Áll. szikes mocsár - } \\
\text { Saline marsh, permanent }\end{array}$ & $-1,0$ & $-1,0$ & $-0,9$ & $-0,7$ & $-0,9$ \\
\hline $\begin{array}{l}\text { Idöszakos szikes mocsár - } \\
\text { Saline marsh, seasonal } \\
\text { intermittent }\end{array}$ & $-1,0$ & $-1,0$ & $-1,0$ & $-0,9$ & $-1,0$ \\
\hline Halastó - Fishpond & $-1,0$ & 0,2 & 0,3 & 0,1 & 0,3 \\
\hline Víztározó - Reservoir & $-1,0$ & 0,8 & 0,8 & 0,7 & 0,8 \\
\hline Bányató - Gravel pit & $-1,0$ & $-1,0$ & $-0,4$ & $-1,0$ & $-0,5$ \\
\hline
\end{tabular}

\subsubsection{Szaporodás}

Ivarérettség: Hasonlóan a többi libafajhoz a vetési ludak életük második évében, azaz a $\sim 15$. hónapban választanak párt maguknak, de rendszerint csak a harmadik évben vezetnek elöször fiatalokat (CRAMP \& SiMMONS, 1977). A tartós párkapcsolat jellemzi ezeket a faj(oka)t is, csak a pár elvesztése esetén keres másik párt magának az egyedült maradt madár (BAUER \& GLUTZ, 1990). A kapcsolat szorosságára utal KALOTÁs (1992) közlése, aki 1990 májusában, 
Dunatetétlenen figyelt meg egy párt, amely egyik tagjának repülési nehézsége miatt a vele párban álló sem vonult el a fészkelö területre, hanem együtt maradva átnyaraltak.

Költési idő: A költési területekre április közepe-május közepe között érkeznek meg. A költés kezdete észak felé haladva elhúzódhat: a költőterület déli részén május elejétől június elejéig, míg északabbra július közepéig. A költöterületeken mindössze 100 napot töltenek (HARRISON, 1975; CRAMP \& SimMONS, 1977; BAUER \& GLUTZ, 1990).

A fészek helye: Többé-kevésbé nyílt, vagy bokrokkal borított helyen költ az A. f. rossicus. Skandináviában előfordul, hogy a száraz erdőtalajra fészkel (A. f. fabalis). A fészkek rendszerint tavak, folyók mocsarak közelében vannak, olykor viszont több száz, esetleg ezer méter távolságra is lehetnek a legközelebbi mocsaras területtöl. A fészkek valamely magaslaton találhatók, amelyek a környezetböl olykor 0,5-1 m-re is kiemelkednek. Jól benépesült élettérben néha száz méterre vannak a fészkek egymástól, általában azonban $2 \mathrm{~km}$ ig változhat távolságuk (MAKATSCH, 1974; HARRISON, 1975; BAUER \& GLUTZ, 1990).

Fészek: A fészek - amelyet a tojó épít - egy sekély, kapart mélyedés, növényi anyagokból (füfélék, lomblevél, moha, zuzmó) készül, amelyeket szárazon helyez a csészébe. A gúnár az anyaggyüjtésben segíthet. A fészektollak barnásszürkék. Ezt követően sötét szürkésbarna pehelytollakkal béleli ki a fészekcsészét. Mivel rendszerint a korábbi fészkelö területekre térnek vissza, használhatják költésre a kitatarozott régi fészket is (HARRISON, 1975; CRAMP \& SimMONS, 1977; BAUER \& GLUTZ, 1990, van den BERG, 1999).

Tojásrakás, költésszám: A tojó a tojásokat naponta rakja le (MAKATSCH, 1974). A fészekalj június közepén teljes. Évente egyszer költ, de fészekalj pusztulása után MAKATSCH (1974) feltételezi sarjúköltését. BAUER \& GLUTZ (1990) szerint viszont a fészekalj elvesztése esetén nincs sarjúfészkelése. Utóbbi lehetőséget támasztja alá a szaporulat nevelésére rendelkezésre álló viszonylag rövid idő. Kedvezőtlen körülmények mellett tehát sok pár költése kimaradhat.

A fészekalj nagysága: Általában (3-)4-6(-7), az .A. f. fabalis alfaj 4-6, az A. f. rossicus 5-7 tojást rak. Olykor megfigyelték 8-9 tojásos fészekalját, ami lehetett összetojás is.

A tojások oválisak, héjuk durvább, mint más Anser fajoké, fénytelenek, színük lerakásukkor sárgásfehér, a kotlás előrehaladtával piszkosszürke árnyalatot kap a fészekanyagtól és a kotló madár tollaitól.

Az átlagos tojásméretek: A. f. fabalis $83,8 \times 55,3 \mathrm{~mm}, 139 \mathrm{~g}, A . f$. rossicus $(\mathrm{n}=5) 78,85 \times$ $51,85 \mathrm{~mm}, 112 \mathrm{~g}$ (MAKATSCH, 1974). Zárttéren tartott példányok ( $\mathrm{n}=53$ ) tojástömege 122-164 (átlag 145) g volt (CRAMP \& SiMMONS, 1977).

Kotlás: Röviddel a teljes fészekalj letojása előtt, vagy közvetlenül az után a tojó elkezdi ülni a tojásokat. Ha elhagyja a fészket, akkor betakarja azt. A kotlás során a gúnár őrzi a fészket. A kotlás 27-29 (25-30) napig tart, a kelés szinkronizált, azaz a kislibák együtt kelnek. A tojáshéjat a fészekben hagyják (MAKATSCH, 1974; HARRISON, 1975; CRAMP \& SiMMONS, 1977, BAUER \& GLUTZ, 1990).

Fiókanevelés: A kislibák fészekhagyók, önállóan táplálkoznak, mindkét szülő védelmezi őket a ragadozókkal szemben. A fiókanevelés 2 hónapig tart, tehát legkorábban augusztus közepén válnak röpképessé. A család a következö költésig együtt marad.

Költési eredmény, halandóság, életkor: A fészkelés eredményessége $85-95 \%$, de feljegyeztek olyan évet, amikor mindössze 4\%-os volt. A repülőssé váláskor - a predációtól függően - 3,1-3,8 fióka/családdal lehet számolni. A populációkban a fiatalok aránya ősszel 30-40\% is lehet (VAN DEN BERG, 1999; BAUER \& GLUTZ, 1990). Gyürüzési adatok szerint 6-7 éves volt a legidősebb jelölt madár, de fogságból 23 évnél korosabb vetési lúd is ismert. 


\subsubsection{Táplálkozás}

A költőterületeken füfélékkel, gyapjúsással, mámorkával, mocsári zsurlóval és zuzmókkal táplálkozik. Magyarországon 1952-1976 között gyüjtött és STERBETZ (1979) által megvizsgált gyomortartalmak főként gabona magvakat, elsősorban kukoricát (41,1 gyakorisági \%), búzát (21,7\%), illetve gyom magvakat (fakó muhar - 6,3\%; közönséges kakaslábfü - 1,71\%) tartalmaztak. Jelentős volt a zöld növényi részek fogyasztása is, ebben ugyancsak a búza levelei $(54,9 \%)$, füfélék $(12,0 \%)$, kiemelten a sziki csenkesz $(8,6 \%)$ játszottak szerepet (2. táblázat). FARAGÓ (1994) a Fertö-tó térségében 1990-1992-ben gyüjtött ( $\mathrm{n}=218)$ gyomortartalmak vizsgálata alapján a kukoricaszemet találta abszolút dominánsnak a vetési lúd táplálékában. A 2 hetes rendszerességgel végzett gyüjtések azt is kimutatták (1. ábra), hogy október-december hónapokban a kukorica betakarítási ütemével együtt folyamatosan

2. táblázat: A vetési lúd táplálék összetétele Magyarországon (STERBETZ 1979) Table 2: Food components of Bean Goose in Hungary (STERBETZ 1979)

\begin{tabular}{|c|c|c|}
\hline A táplálék neme & $\begin{array}{c}\text { Elöfordulási esetek } \\
\text { száma }\end{array}$ & Darabszám \\
\hline $\begin{array}{l}\text { 1. Zöld növényi részek } \\
\text { Triticum vulgare } \\
\text { Gramineae spp. } \\
\text { Festuca pseudovina } \\
\text { Chara spp. (algák) } \\
\text { Achillea spp. } \\
\text { Taraxacum officinale } \\
\text { Suaeda maritima } \\
\text { Sinapis spp. } \\
\text { Allium spp. }\end{array}$ & $\begin{array}{c}96 \\
21 \\
15 \\
7 \\
3 \\
3 \\
2 \\
1 \\
1\end{array}$ & $\begin{array}{l}x \\
X \\
x \\
x \\
x \\
x \\
x \\
x \\
x\end{array}$ \\
\hline $\begin{array}{l}\text { 2. Magvak } \\
\text { Zea mays } \\
\text { Triticum vulgare } \\
\text { Setaria pumila } \\
\text { Oryza sativa } \\
\text { Polygonum spp. } \\
\text { Hordeum vulgare } \\
\text { Bolboschoenus maritimus } \\
\text { Echinochloa crus-galli } \\
\text { Amaranthus retroflexus } \\
\text { Suaeda maritima } \\
\text { Robinia pseudo-acacia. } \\
\text { Carex spp. }\end{array}$ & $\begin{array}{c}72 \\
38 \\
11 \\
6 \\
6 \\
4 \\
4 \\
3 \\
3 \\
2 \\
1 \\
1 \\
\end{array}$ & $\begin{array}{c}16461+x \\
78660+x \\
8654+x \\
7803 \\
329 \\
65 \\
18 \\
8322 \\
814 \\
192 \\
300 \\
6 \\
\end{array}$ \\
\hline $\begin{array}{l}\text { 3. Állati táplálék } \\
\text { Zabrus tenebrioides imago } \\
\text { Kitin }\end{array}$ & $\begin{array}{l}1 \\
1\end{array}$ & $\begin{array}{l}\mathrm{x} \\
\mathrm{x}\end{array}$ \\
\hline $\begin{array}{l}\text { 4. Zúzóanyag } \\
\text { Homok és kavics } \\
\text { Csigamaradványok }\end{array}$ & $\begin{array}{c}160 \\
35\end{array}$ & $\begin{array}{l}\mathrm{x} \\
\mathrm{x}\end{array}$ \\
\hline
\end{tabular}


növekedett e táplálék fogyasztása, majd az őszi talajmunkák befejeztével, a hótakaró kialakultával és a táplálékkészlet kimerülésével átvette a vezető táplálékforrás szerepét az őszi gabona, föként az őszi búza levele-hajtása. Egymást követő két szezon vizsgálati eredményei sem mutattak ebben eltérést. A nagyfokú táplálékspecializáció is megfigyelhető volt, a megvizsgált gyomrok 88,3\%-ában csupán egyféle, 10,6\%-ában kétféle, 1,1\%-ában háromféle táplálék volt fellelhető.

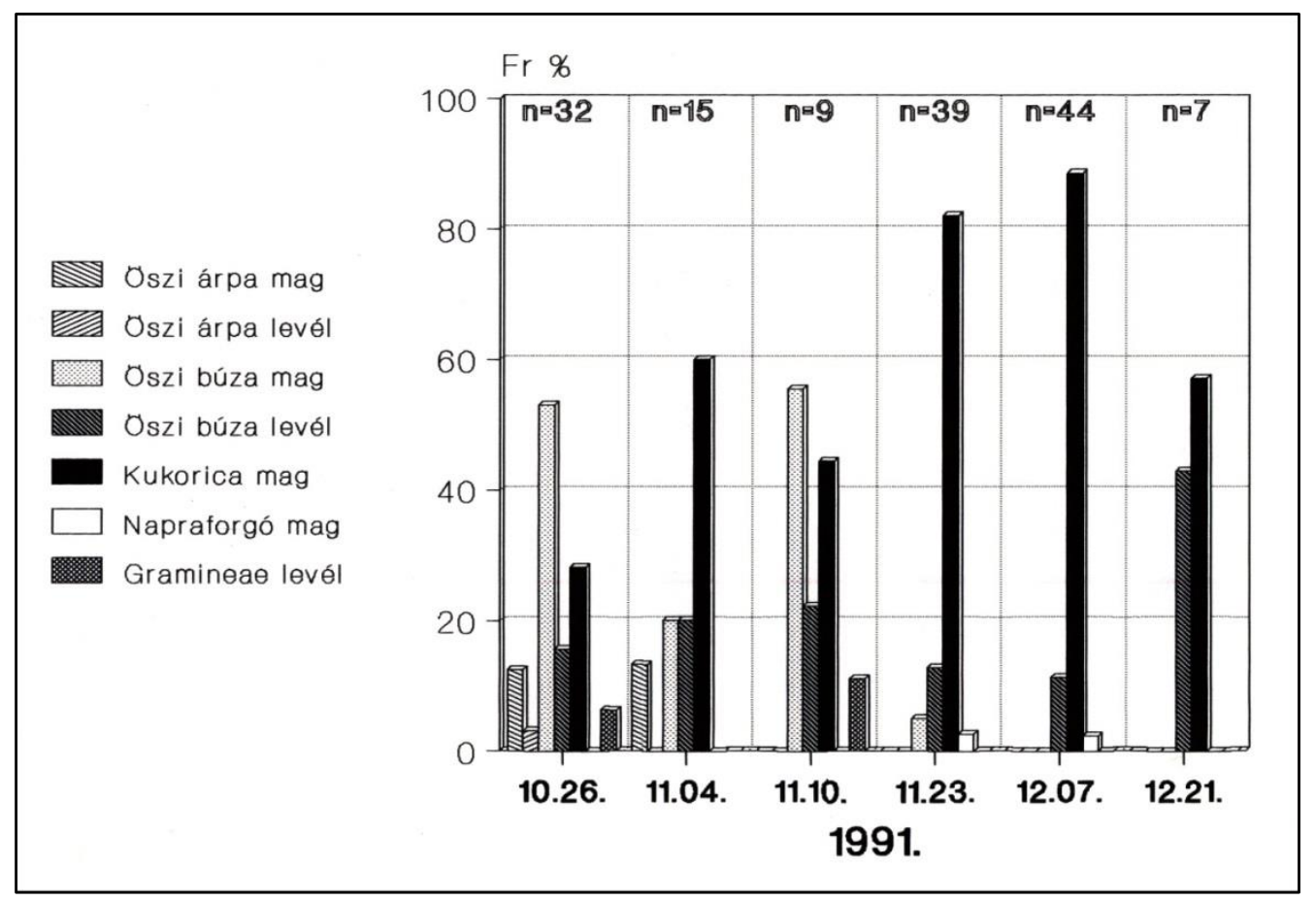

1. ábra: A vetési lúd táplálék-összetevőinek változása október-december folyamán, a Fertőn 1991-ben (FARAGÓ, 1994).

Figure 1: Change of food components of Bean Goose between October and December in year 1991 at the Lake Fertö/Neusiedl (FARAGÓ, 1994)

\subsection{ELTERJEDÉS}

Fészkelő területe Izlandtól, a Spitzbergáktól, Közép- és Észak-Skandináviától KeletSzibériáig húzódik (1. térkép). Ezen elterjedési területen belül a tudomány 5 alfaj és két színváltozat létét fogadja el (BAUER \& GLUTZ, 1990; CRAMP \& SimMONS, 1977; SCOTT \& Rose, 1996; RuTSCHKE, 1987, 1997). Ezek közül kettő tundrai ( $A$. $f$. rossicus és $A . f$. serrirostris), három pedig tajgai alfaj (A.f. fabalis, $A$. f. middendorfi és $A$. f. johanseni). A faj elterjedésének nyugati része az A.f. fabalis és $A$. $f$. rossicus, a keleti pedig az A. $f$. serrirostris és $A$. $f$. middendorfi költőterülete. A középső, erdős terület nyugati részén - korábban úgy tartották - az A. f. fabalis és az A. f. rossicus alfaj erősen keveredik, s Európába elsősorban e két alfaj és kevert állományai jutnak el.

SANGSTER \& OREEL, 1996; SANGSTER et al., 1999) teljesen új alapokra helyezték a vetési lúd rendszertanát. Ezek a nézetek széles körben még mind a mai napig nem elfogadottak, de nem érdektelen megismerkedni velük. Eszerint a vetési ludat, mint fajkomplexet tekintik, amelyen belül 3 jól elkülönülő fajt különítenek el: (1) a rövidcsőrü ludat (Anser brachyrhynchus), (2) a tajgai vetési ludat (Anser fabalis) és (3) a tundrai vetési ludat (Anser serrirostris). Az utóbbi két faj - megállapításuk szerint - méreteiben, hangadásában, táplálkozó élőhelyeiben és táplálékában, fényérzékenységében, aktivitásainak mintázatában, viselkedésében, fenológiájában, a különlegesen hideg viszonyokra adott 
válaszaiban különül el egymástól. A gyürüzési adatok is azt mutatják, hogy a tajgai és a tundrai vetési lúd eltérő költési elterjedésű (előbbi fészkelő helyei főként az Uráltól K-re, utóbbiaké az Uráltól Ny-ra találhatók), nyilvánvalóan nincs „fokozatos átmenet” közöttük. Mivel a közös telelőterületeken megkezdődő párba állás során a két faj között gyakorlatilag nincs kereszteződés, ezért a biológiai faj-fogalom értelmében ugyancsak jól elkülönülnek egymástól. Mind a két faj testméreteiben földrajzi változatokat lehet kimutatni, egy következetes klinális (ez esetben földrajzi szélességi körök menti) változat-mintázatban, ezért az A. fabalis magában foglalja a johanseni és middendorfi alfajt, az A. serrirostris pedig a rossicus alfajt. A SUSKIN-lúd (Anser neglectus) nevet mindkét faj rózsaszín, vagy hússzínü lábú, a BuTURLIN-lúd (Anser carneirostris) nevet ugyancsak mindkét faj rózsaszín, vagy hússzínü csőrü, de (normál) sárga lábú egyedeire használják (SANGSTER \& OREEL, 1996; SANGSTER et al., 1999).

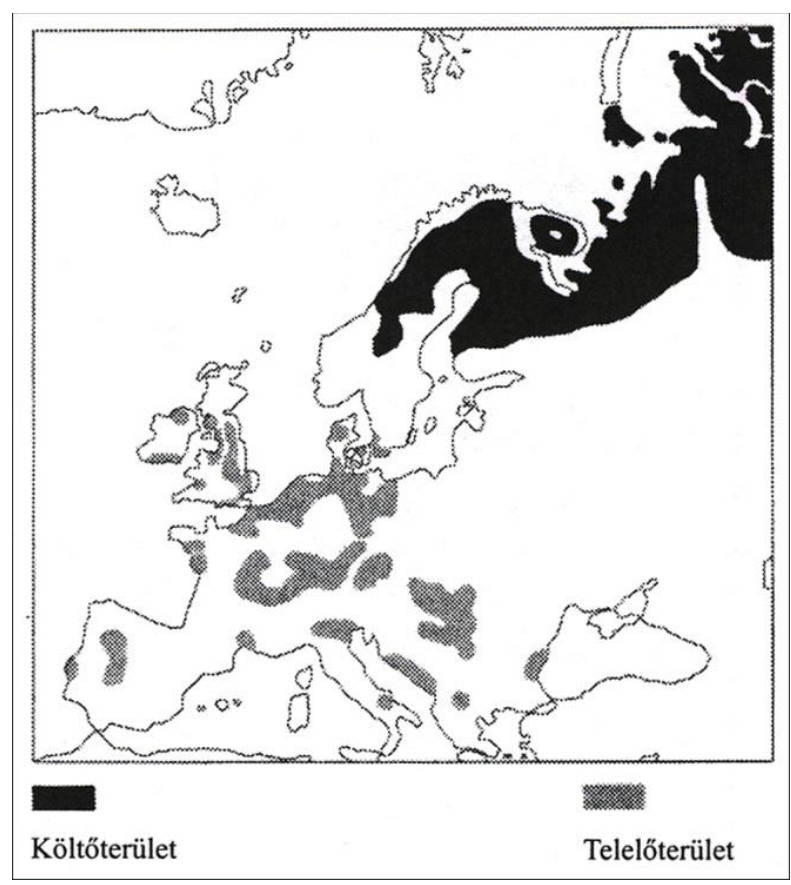

1. térkép: A vetési lúd elterjedése Európában (JONSSON, 1993) Map 1: Distribution of Bean Goose in Europe (JONSSON, 1993)

KEVE (1984) korábbi megállapítása szerint hazánkban tömegesen az A. f. fabalis törzsalak vonult át, mindössze 15 pld tipikus $A$. $f$. rossicusról és 2 pld $A$. $f$. johanseni-röl tudott. Írta ezt annak ellenére, hogy az általa JOHANSENnek küldött 90 vetési lúd fejről kiderült, hogy azok zömét az A. fabalis $\times$ rossicus alfajok átmeneti formái tették ki, s alig talált tipikus fabalis, vagy rossicus példányt (JOHANSEN, 1962). Ezzel szemben HuYSKENS (1986) szerint Magyarországon főként az Anser f. rossicus vonul át. A Magyarország madarainak névjegyzéke legutóbbi kiadása szerint (MME NoMENCLATOR BIzOTTSÁG, 2008) szerint az $A$. $f$. rossicus a leggyakoribb vetési lúd alfaj Magyarországon, az A. $f$. fabalis kis számban jelenik meg. Az A. f. johanseni előfordulását csak 2 esetben mutatták ki (MAGYAR et al., 1998). Saját vizsgálataink szerint is Magyarországon az A. f. rossicus alfaj a domináns, de emellett megfigyelhetö az A. f. fabalis, az A. $f$. johanseni, az A. f. serrirostris is (van den BERG szem.közl.).

Az egykor önálló fajként elkülönített SuSKIN-lúd (Anser neglectus) - amely hazánkban is előfordult, s STERBETZ (1981) értekezett etológiájáról és ökológiájáról - és BUTURLIN-lúd (Anser carneirostris) színváltozatoknak tekintendők (JOHANSEN, 1962). 


\subsection{VÁNDORLÁS ÉS TELELÉS}

A vetési ludak vonulása Európában egyrészt az Ibériai-félsziget és az Atlanti-óceán partvidéke illetve a Pannon-régió felé irányul. E két területre két vonulási útvonalon érkeznek a vetési ludak: (1) fehér-tengeri/balti-tengeri útvonal, (2) kontinentális útvonal. A tengerpartot követő populáció - amely a Kola- és Kanin-félszigeten, a Malozemelszkaja és Balsozemelszkaja tundrán fészkel - a lengyel-német-holland-belga telelőhelyekre vonul, egy részük azután télközi köztes vonulással eléri a Pannon-régiót is. A másik vonulási úton közlekedők - amelyek a Novaja Zemlján, a Jamal- és Gidán-félszigeten továbbá a Tajmirfélsziget Ny-i részén fészkelnek - az Ob folyását, majd az Uralt követve Ny-ra fordulnak, s Fehéroroszország térségében kettéválnak. Egyik (nagyobb) részük célterülete ugyancsak a Lengyel-német síkság, míg másik (kisebb) részük közvetlenül a Pannon-régióba vonul. E két terület között ugyancsak határozott kapcsolat van (van den BERG, 1999) (2-3. térkép). A Pannon-régió tehát - amelybe hazánk is beletartozik - a vetési lúd egyik legfontosabb vonuló és telelö területe.

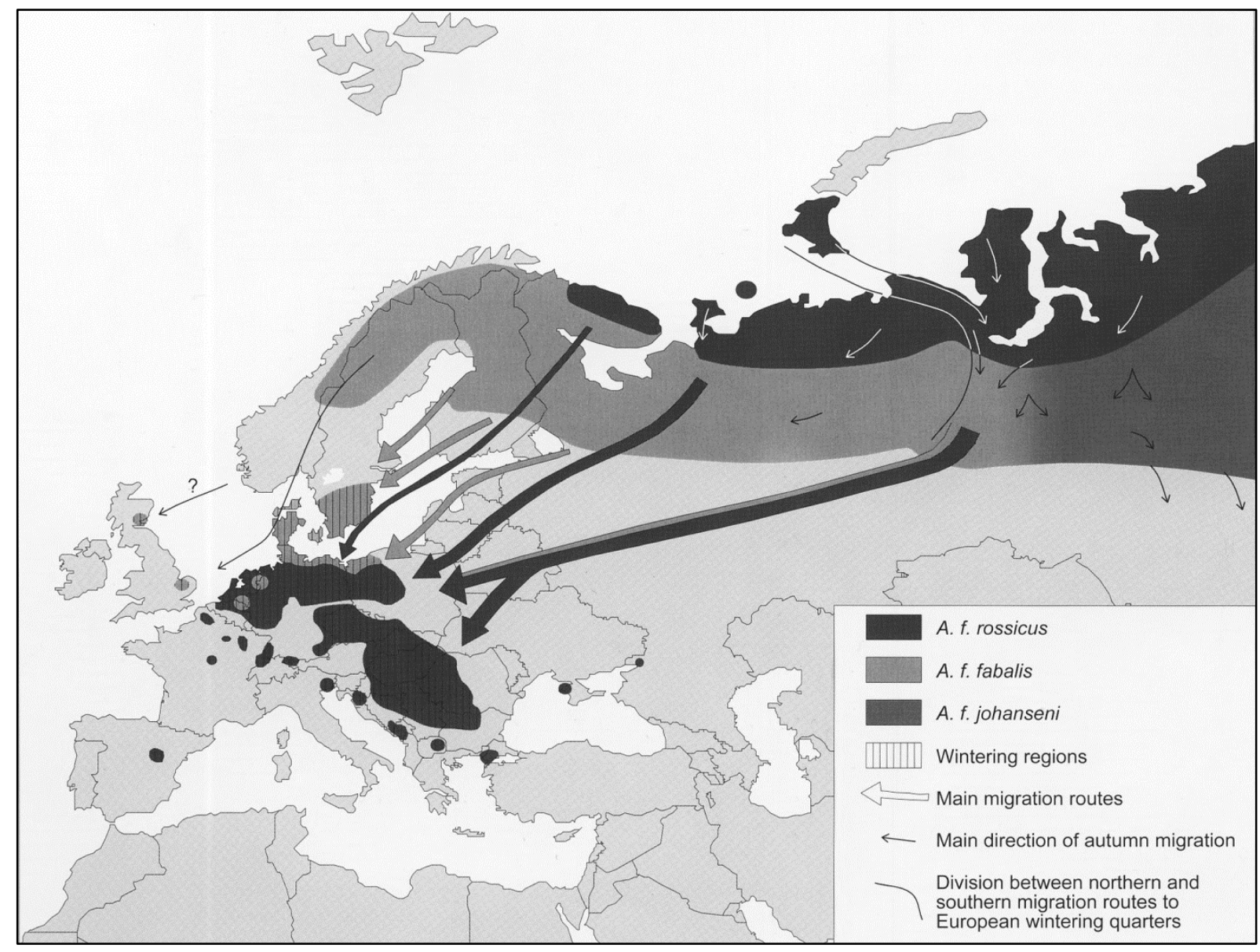

2. térkép: A vetési lúd alfajok elterjedése, vonulási útvonalai és telelőterületei az ezredfordulón, Eurázsiában (VAN DEN BERG et al., 1999)

Map 2: Distributions, migration routes and wintering areas of Bean Goose subspecies at the millennium in Eurasia (VAN DEN BERG et al., 1999) 


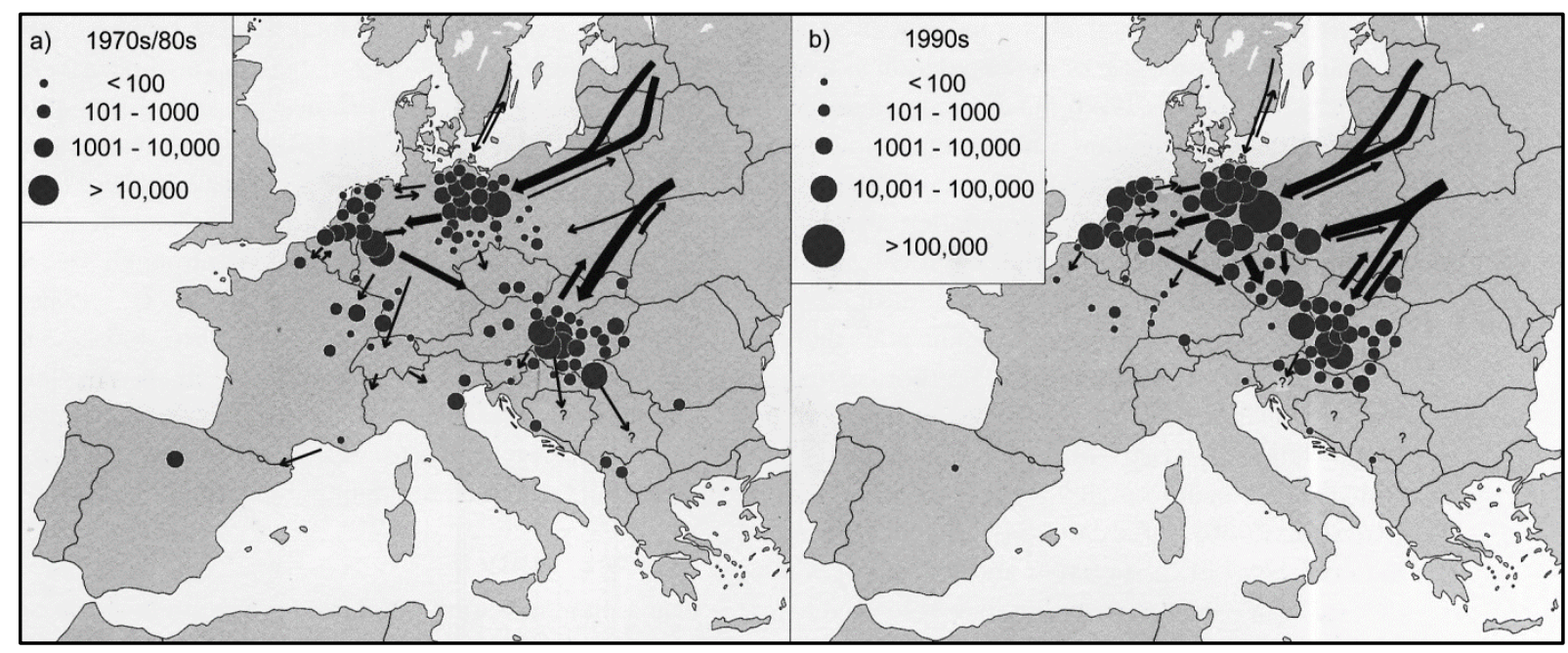

3. térkép: Változások a tundrai vetési lúd (Anser fabalis rossicus) vonulásában és telelésében az európai területeken (VAN DEN BERG et al., 1999)

(a) az 1970-es és 1980-as években, (b) az ezredfordulón

Map 3: Change in migration and wintering of Tundra Bean Goose (Anser fabalis rossicus)in Europe (VAN DEN BERG et al., 1999)

A vetési lúd szeptember végén érkezik hozzánk, és legkésőbb áprilisban távozik hazánkból. Enyhe telek után már március végére eltűnhet vizeinkről. A Dunántúlra előbb, az Alföldre később érkezik meg, amit az északi fészkelési és vonulási területek időjárási viszonyai is befolyásolnak (2. ábra).

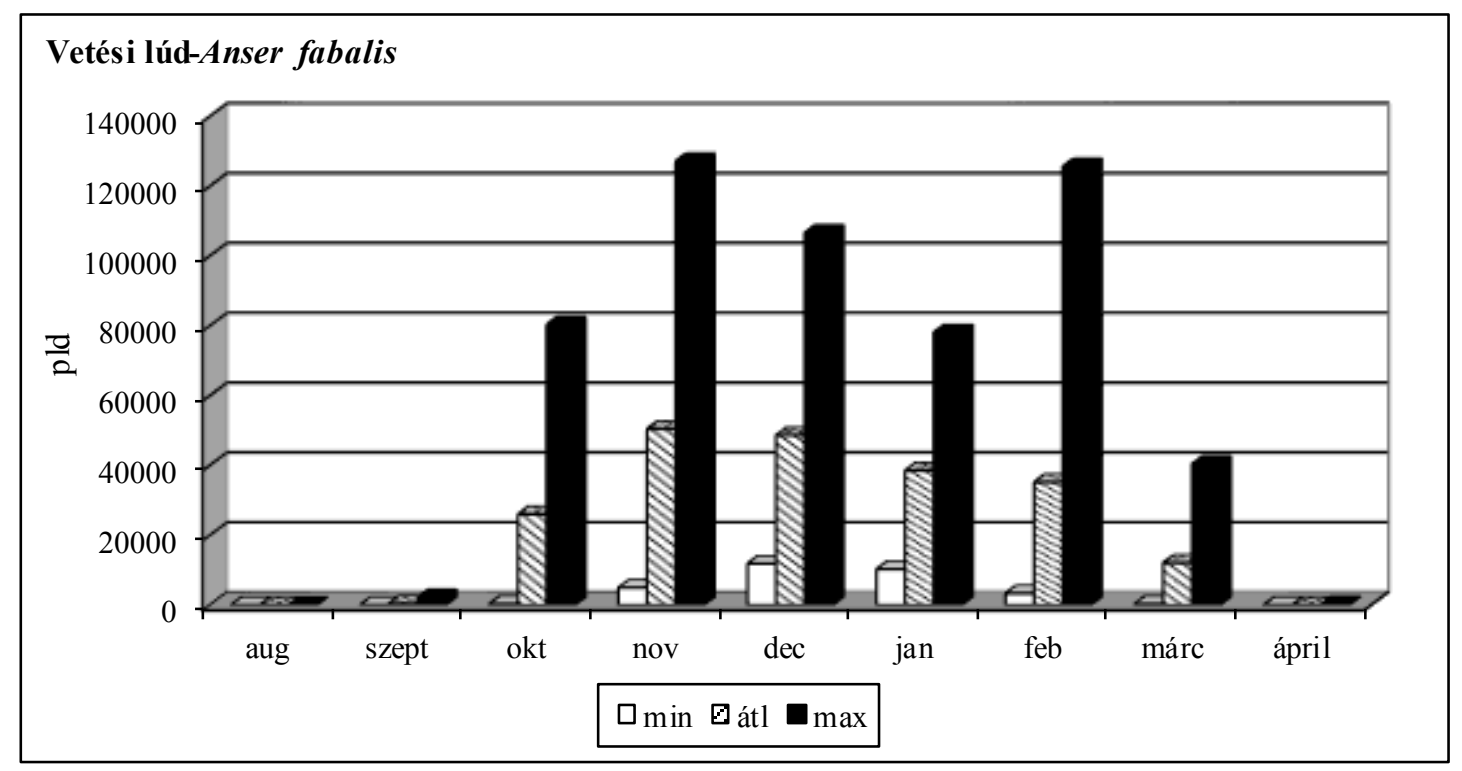

2. ábra: A vetési lúd fenológiája Magyarországon

Figure 2: Phenology of Bean Goose in Hungary

Magyarországon megkerült $(\mathrm{n}=116)$ vetési ludak zömét (51 pld) Németországban, Hollandiában (47 pld) és Oroszországban $(n=18)$ gyürüzték. Ismert egy orosz példány, amelyet a Jenyiszej torkolatában jelöltek meg és még ugyanazon év őszén jelölési helyétől 4107 km-re került kézre. 1996 júliusában, a Dolgaja-öbölben, a Vajgah-szigeten jelölt vetési ludakból 4 pld még ugyanazon telelési idényben (XII-I) - jelölési helyétől $\sim 3300 \mathrm{~km}$-re került meg Magyarországon. 


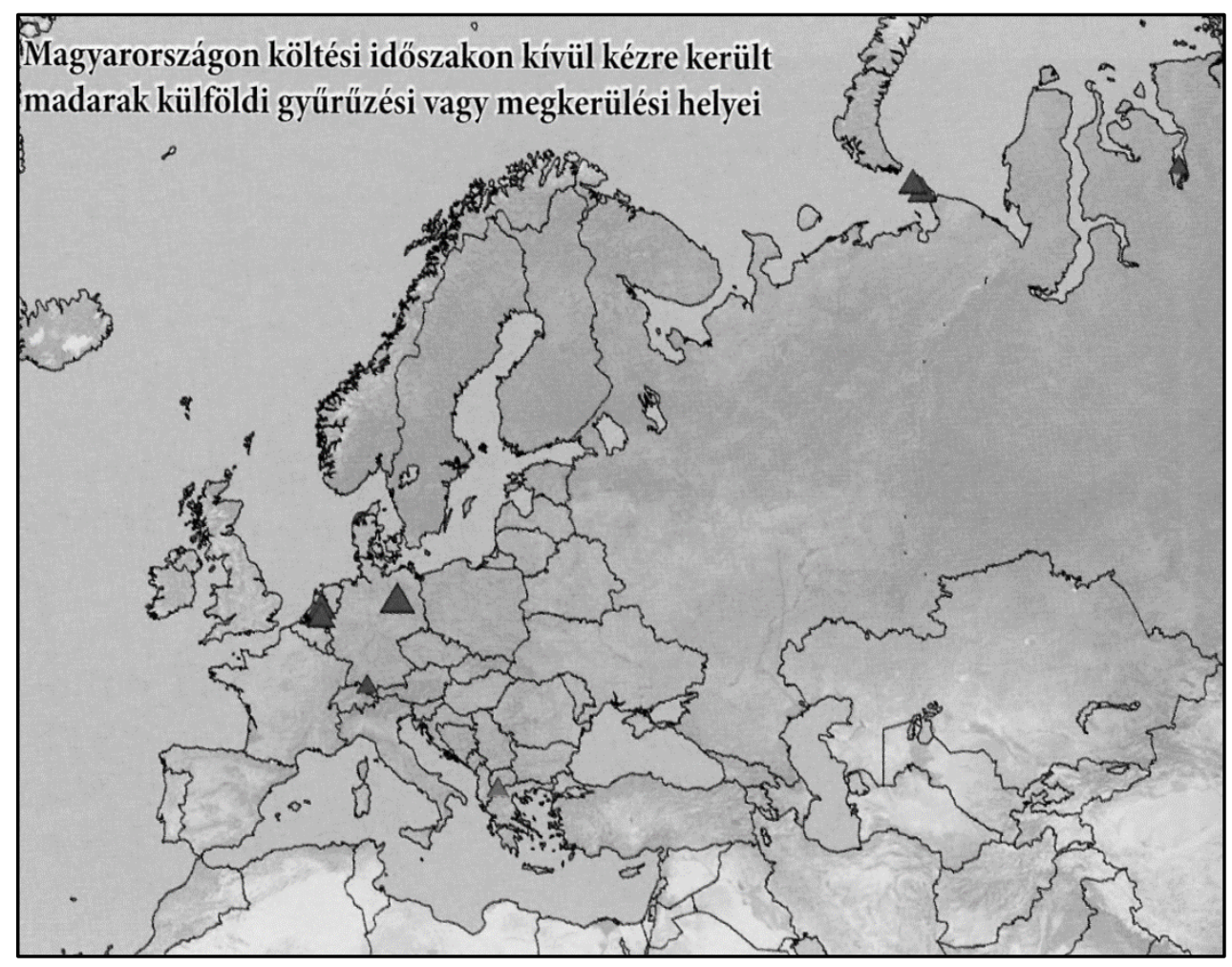

4. térkép: Magyarországon a költési időszakon kívül kézre került vetési ludak külföldi gyürüzési, vagy megkerülési helyei (FARAGÓ \& PELLINGER, 2009)

Map 4: Foreign ringing or recovery location of Bean Goose observed in Hungary outside the breeding season (FARAGÓ \& PELLINGER, 2009)

A Magyarországon jelölt madarak szinte egész Közép-Európát (Ausztria, Szlovákia, Csehország, Lengyelország, Németország, Hollandia) bejárták, de van már 3 orosz visszajelzés, sőt a déli továbbvonulást igazoló macedón megfigyelés is (4. térkép) (FARAGÓ, 2000; FARAGÓ \& PELLINGER, 2009).

\section{5. ÁllomÁNYNAGYSÁG}

Az A. f. fabalis korábbi világállománya mintegy 100000 pld-ra volt tehető (MADSEN et al., 1999), bár Rose \& SCOTT (1997) csak 80000 pld-t, HuYSKENS (1999) 85000 pld-t adott meg. A 10 évvel korábbi telelö állománya még mintegy 130000 pld volt (BURGERS, 1990). Mára ez a létszám 40 000-45 000 pld-ra csökkent (WETLANDS INTERNATIONAL, 2015).

Az A. $f$. rossicus alfaj Közép- és Ny-Európában telelő állományát a számlálások kiterjedtebbé válásával együttesen már mintegy 600.000 pld-nak becsülték (MADSEN et al., 1999; van den BERG, 1999). Korábban ennek csak felét, 300000 pld-t adtak meg (RoSE \& SCOTT, 1997). A legújabb becslések 550000 pld-t adnak meg (WETLANDS InTERNATIONAL, 2015).

A hazai állományváltozásról ugyanezen szinkron számlálások alapján vannak egyre pontosabb ismereteink (3. táblázat; 3. ábra). Az 1950-es években tapasztalható nagyarányú fogyatkozás után, az 1970-es évekre elöször lassú, majd gyors állománynövekedés következett be. Ennek mértéke a vetési lúdnál mintegy 43\%-os volt. Az átlagos novemberi maximum 36500 pld, a decemberi 28900 pld volt. Az 1980/1981-es idényben pedig bekövetkezett a nagy váltás is, a Magyarországon vonuló és telelö vadludak között a vetési lúd átvette a vezető szerepet. Korábban 10-44\%-nyi részesedése, 1980/1981-ben már 75\% volt (STERBETZ, 1983). Ezt követően a vetési lúd állománynövekedése a korábbinál is 
intenzívebbé vált, 1984 novemberében 196750 pld-nyal tetőzött (FARAGÓ et al., 1991). Az 1980-as évek közepétől észlelt csökkenése után, a korábbi csúcsmennyiségnek csak feleharmada jelent meg. Megfogyatkozását részben az enyhe telekre, részben a hosszú száraz periódusra vezettük vissza. Enyhe teleken a tölünk É-ra fekvő területeken (Németország, Csehország) megreked a vonulás. A csapadék hiánya elsősorban az Alföldön eredményezte a vetési lúd visszaszorulását. Az 1990-es évek közepe óta tapasztalható változatlanul alacsony tetőző egyedszámok a kárpótlásokkal megszűnt nagyüzemi kukoricatarlók kínálta táplálékbőség elmaradására vezethetők vissza. A mennyiségi tetőzés idején novemberben/decemberben átlagosan 92 400/71 600 pld, maximum 196750/106 620 pld is elöfordulhatott.

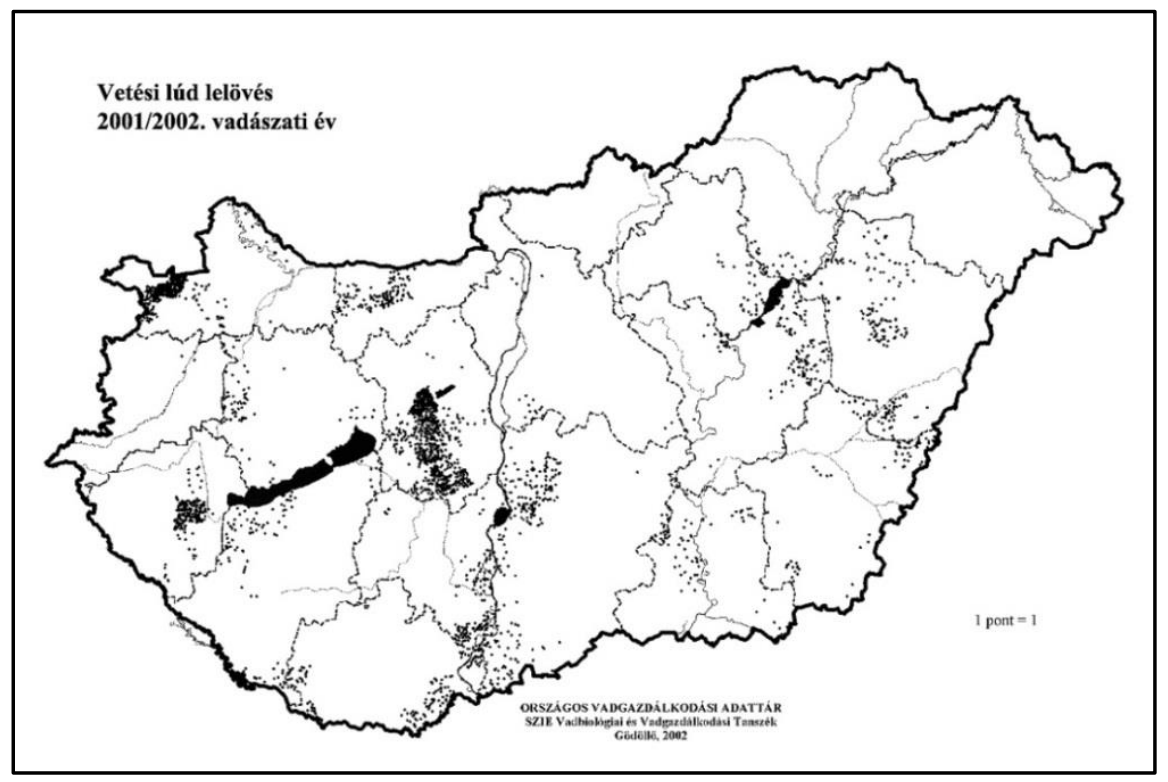

5. térkép: A vetési lúd elterjedése (teríték alapján) Magyarországon 2001/2002-ben (CSÁNYI, 2002).

Map 5: Distribution of Bean Goose (after bags) in Hungary in 2001-2002 (CSÁNYI, 2002)

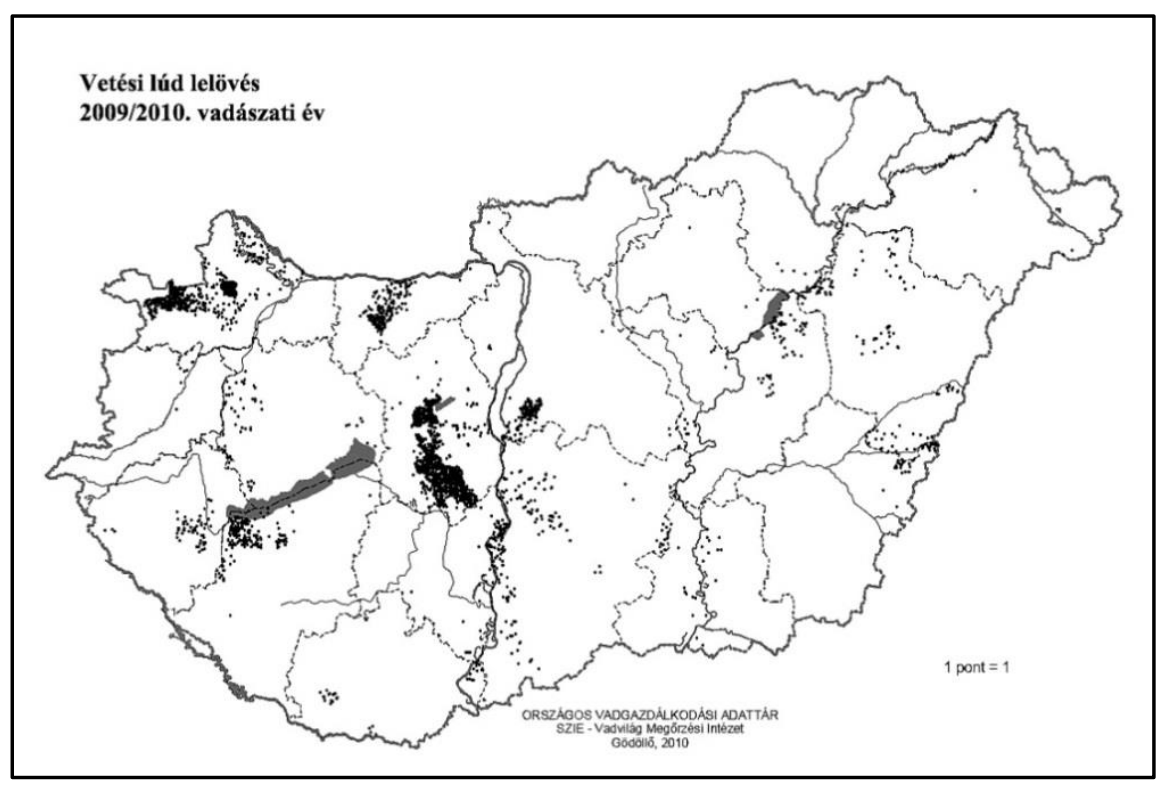

6. térkép: A vetési lúd elterjedése (teríték alapján) Magyarországon 2009/2010-ben (CSÁNYI et al., 2010).

Map 6: Distribution of Bean Goose (after bags) in Hungary in 2009-2010 (CsÁNYI et al., 2010) 


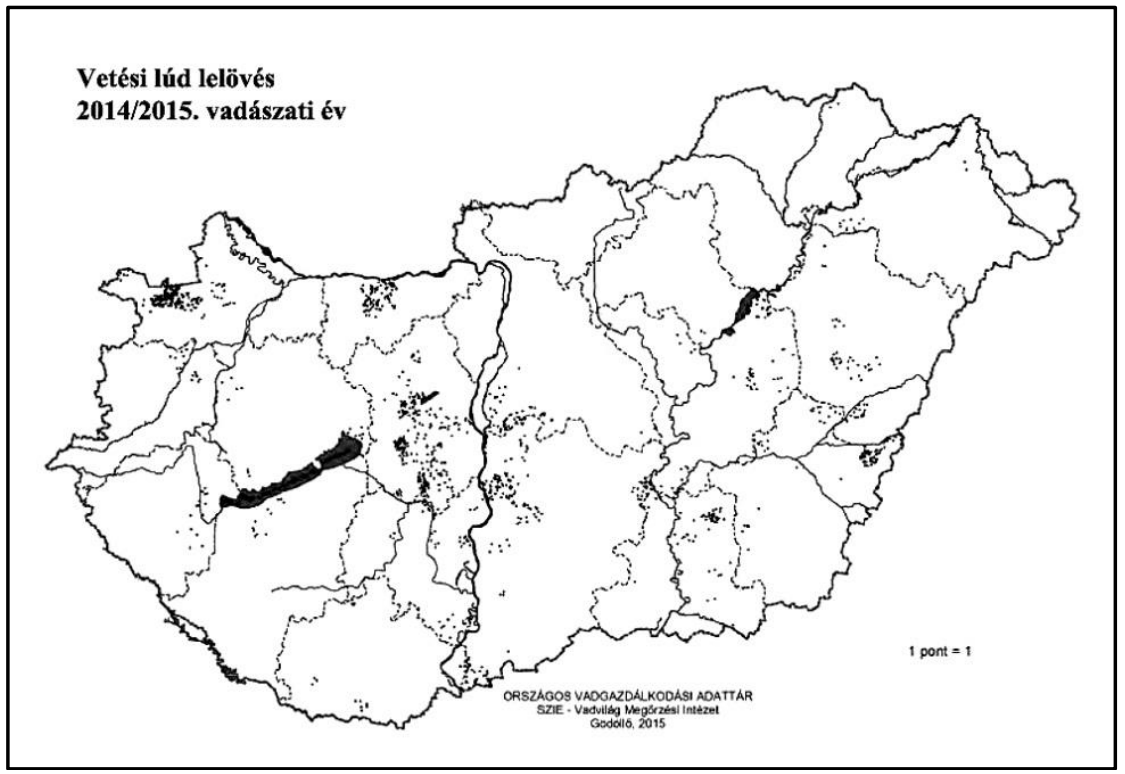

7. térkép: A vetési lúd elterjedése (teríték alapján) Magyarországon 2014/2015-ben (CSÁNYI et al., 2015).

Map 7: Distribution of Bean Goose (after bags) in Hungary in 20014-2015 (CSÁNYI et al., 2015)

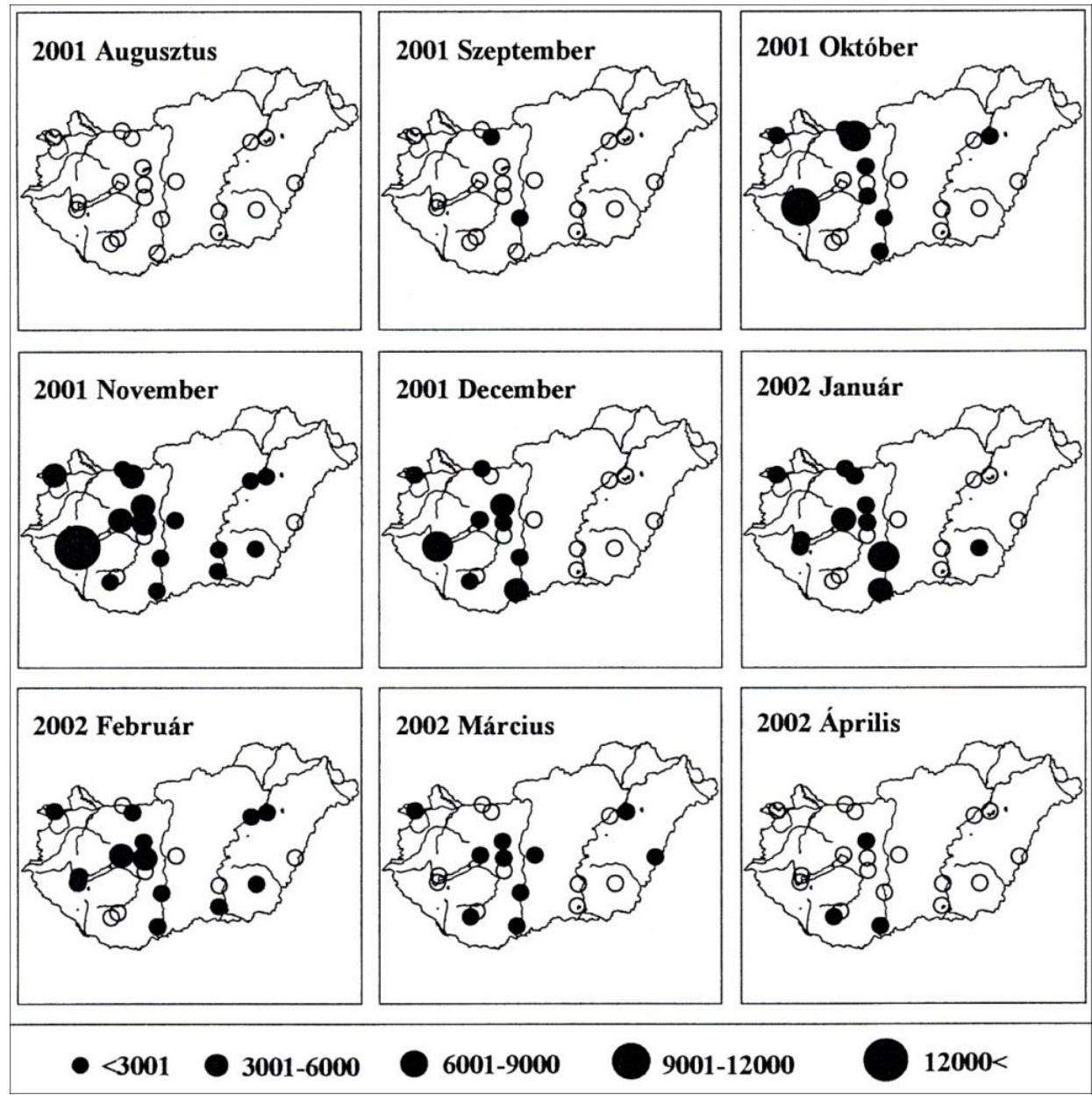

8. térkép: A vetési lúd előfordulás tér-idő mintázata Magyarországon 2001/2002-ben (FARAGÓ \& GOSZTONYI, 2003).

Map 8: Spatial and temporal pattern of Bean Goose in Hungary, 2001-2002 (FARAGÓ \& GosZTONYI, 2003) 
3. táblázat: Magyarország vetési lúd állományának alakulása a Magyar Vízivad Monitoring számlálásai szerint az elmúlt 29 évben (1986-2015)

Table 3: Population number of Hungarian Bean Goose population on the basis of the censuses of Hungarian Waterfowl Monitoring in the last 29 seasons (1986-2015)

\begin{tabular}{|c|c|c|c|c|c|c|c|c|c|}
\hline Szezon & Aug. & Szept. & Okt. & Nov. & Dec. & Jan. & Febr. & Márc. & Ápril. \\
\hline \hline $\mathbf{1 9 8 6 / 1 9 8 7}$ & $*$ & $*$ & 71408 & 114716 & 106620 & 52161 & 14435 & 24248 & $*$ \\
\hline $\mathbf{1 9 8 7 / 1 9 8 8}$ & $*$ & $*$ & 60629 & 99818 & 73190 & 45561 & 45739 & 10623 & $*$ \\
\hline $\mathbf{1 9 8 8 / 1 9 8 9}$ & $*$ & $*$ & 27983 & 94983 & 86639 & 43677 & 43830 & 11454 & $*$ \\
\hline $\mathbf{1 9 8 9 / 1 9 9 0}$ & $*$ & $*$ & 19637 & 60647 & 57146 & 13787 & 20706 & 1121 & $*$ \\
\hline $\mathbf{1 9 9 0 / 1 9 9 1}$ & $*$ & $*$ & 38472 & 80796 & 30969 & 54306 & 37470 & 10641 & $*$ \\
\hline $\mathbf{1 9 9 1 / 1 9 9 2}$ & $*$ & $*$ & 80307 & 127145 & 80604 & 78062 & 125667 & 36337 & $*$ \\
\hline $\mathbf{1 9 9 2 / 1 9 9 3}$ & $*$ & $*$ & 47380 & 63186 & 57905 & 47129 & 30867 & 33302 & $*$ \\
\hline $\mathbf{1 9 9 3 / 1 9 9 4}$ & $*$ & $*$ & 48922 & 43240 & 78291 & 70268 & 79812 & 14852 & $*$ \\
\hline $\mathbf{1 9 9 4 / 1 9 9 5}$ & $*$ & $*$ & 64824 & 111691 & 100167 & 56996 & 73727 & 5937 & $*$ \\
\hline $\mathbf{1 9 9 5 / 1 9 9 6}$ & $*$ & $*$ & 29767 & 75874 & 48343 & 37597 & 17989 & 40405 & $*$ \\
\hline $\mathbf{1 9 9 6 / 1 9 9 7}$ & $*$ & $*$ & 43383 & 56178 & 80247 & 36681 & 46653 & 7526 & $*$ \\
\hline $\mathbf{1 9 9 7 / 1 9 9 8}$ & $*$ & $*$ & 17133 & 41972 & 71733 & 54944 & 76851 & 9576 & 4 \\
\hline $\mathbf{1 9 9 8 / 1 9 9 9}$ & $*$ & 2252 & 37013 & 52136 & 58303 & 74490 & 64795 & 26700 & 204 \\
\hline $\mathbf{1 9 9 9 / 2 0 0 0}$ & $*$ & 356 & 13084 & 51139 & 57099 & 38735 & 28377 & 5721 & 1 \\
\hline $\mathbf{2 0 0 0 / 2 0 0 1}$ & $*$ & 1260 & 15797 & 33847 & 27067 & 38995 & 23267 & 1547 & 71 \\
\hline $\mathbf{2 0 0 1 / 2 0 0 2}$ & $*$ & 801 & 20227 & 44395 & 24565 & 24204 & 15350 & 2241 & 102 \\
\hline $\mathbf{2 0 0 2 / 2 0 0 3}$ & $*$ & 0 & 9559 & 30149 & 30287 & 29002 & 31589 & 22268 & 190 \\
\hline $\mathbf{2 0 0 3 / 2 0 0 4}$ & $*$ & 510 & 5750 & 42623 & 38211 & 37754 & 27253 & 6430 & 10 \\
\hline $\mathbf{2 0 0 4 / 2 0 0 5}$ & 0 & 500 & 8613 & 21056 & 30750 & 26291 & 25152 & 21031 & 20 \\
\hline $\mathbf{2 0 0 5 / 2 0 0 6}$ & 0 & 0 & 5233 & 14669 & 33738 & 33014 & 44756 & 11435 & 0 \\
\hline $\mathbf{2 0 0 6 / 2 0 0 7}$ & 0 & 0 & 7750 & 13651 & 26628 & 48328 & 8968 & 857 & 0 \\
\hline $\mathbf{2 0 0 7 / 2 0 0 8}$ & 0 & 0 & 879 & 13369 & 13903 & 12800 & 3702 & 1590 & 0 \\
\hline $\mathbf{2 0 0 8 / 2 0 0 9}$ & 0 & 0 & 296 & 6160 & 12898 & 14260 & 3343 & 270 & 70 \\
\hline $\mathbf{2 0 0 9 / 2 0 1 0}$ & 0 & 0 & 610 & 8285 & 13192 & 12660 & 9341 & 2548 & 0 \\
\hline $\mathbf{2 0 1 0 / 2 0 1 1}$ & 0 & 4 & 757 & 4953 & 11835 & 10542 & 11702 & 2853 & 15 \\
\hline $\mathbf{2 0 1 1 / 2 0 1 2}$ & 0 & 0 & 900 & 5027 & 13404 & 10254 & 4072 & 2615 & 0 \\
\hline $\mathbf{2 0 1 2 / 2 0 1 3}$ & 0 & 0 & 133 & 2349 & 2980 & 8999 & 6735 & 2032 & 0 \\
\hline $\mathbf{2 0 1 3 / 2 0 1 4}$ & 0 & 50 & 453 & 2811 & 6630 & 3188 & 1743 & 300 & 13 \\
\hline $\mathbf{2 0 1 4 / 2 0 1 5}$ & 0 & 26 & 183 & 968 & 953 & 1628 & 525 & 384 & 152 \\
\hline
\end{tabular}

Forrás: FARAGÓ (1995, 1996, 1997a, 1999, 2001,2002a, 2002b, 2005, 2006a, 2007a, 2007b, 2008b, 2010a, 2010b, 20110, 2011b, 2012, 2014, 2015, 2016); FARAGÓ \& GOSZTONYI (2003); FARAGÓ \& JÁNOSKA (1996) 

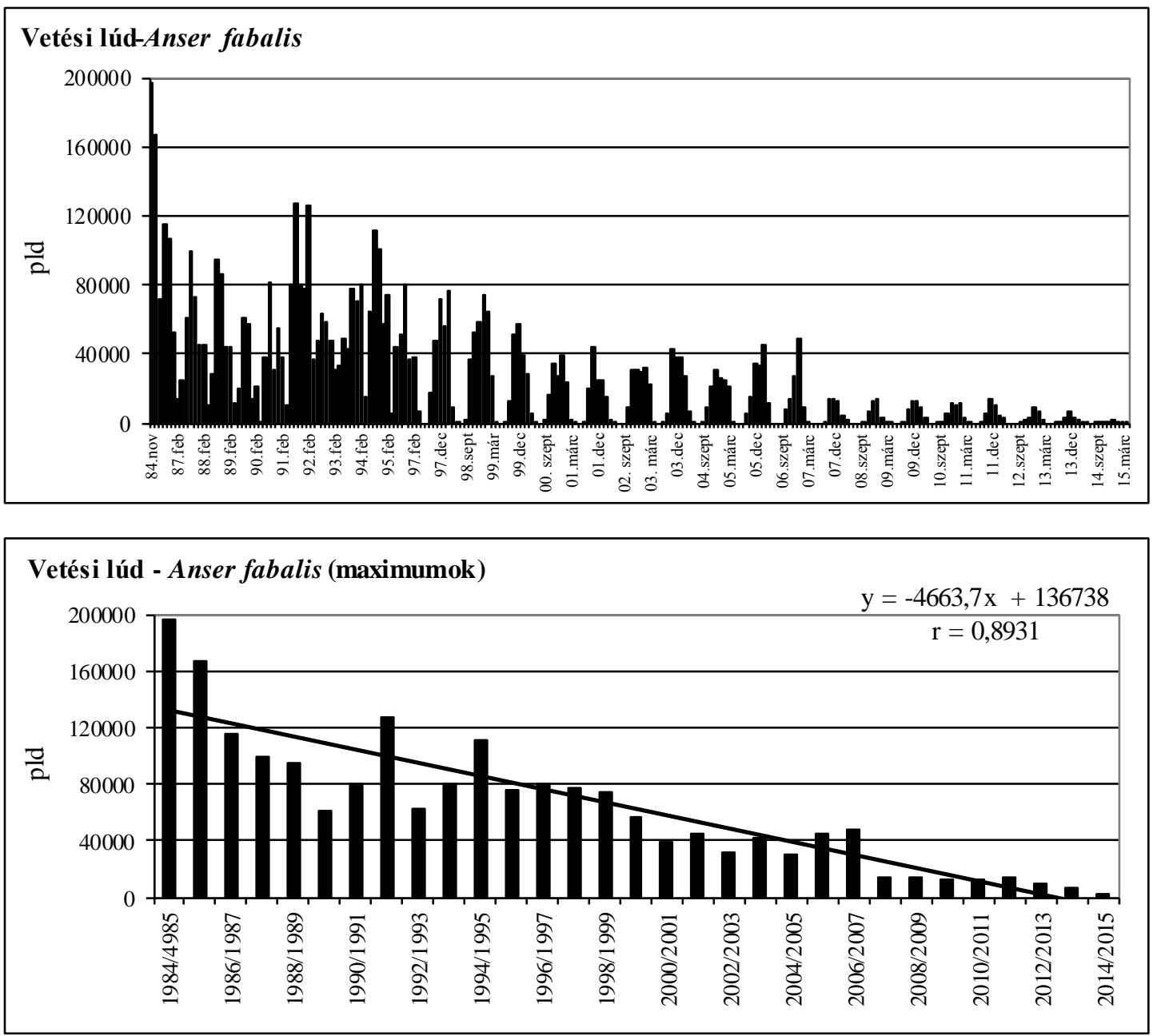

Vetési lúd - Anser fabalis

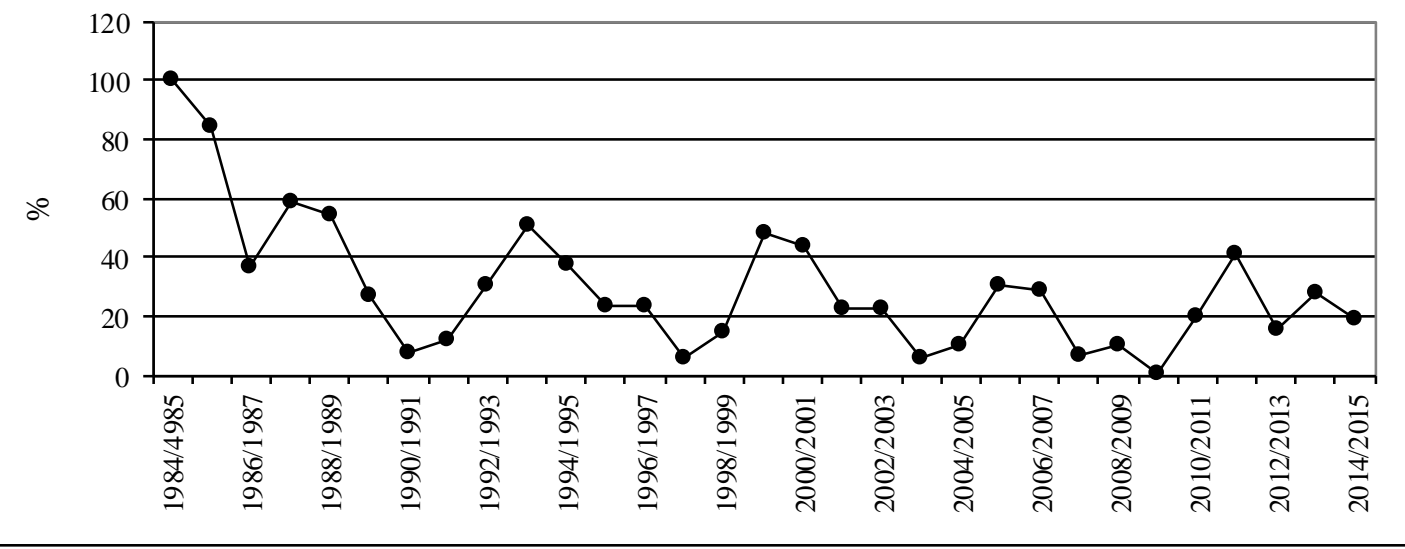

3. ábra: Magyarország vetési lúd állományának havi dinamikája, az éves maximumok trendje és a maximum indexek, 1984-2015 (a Magyar Vízivad Monitoring számlálásai szerint) Figure 3: Monthly dynamics, trend of yearly maximums and maximum indices for Bean Goose in Hungary, 1984-2015 (after investigations of Hungarian Goose Monitoring) 


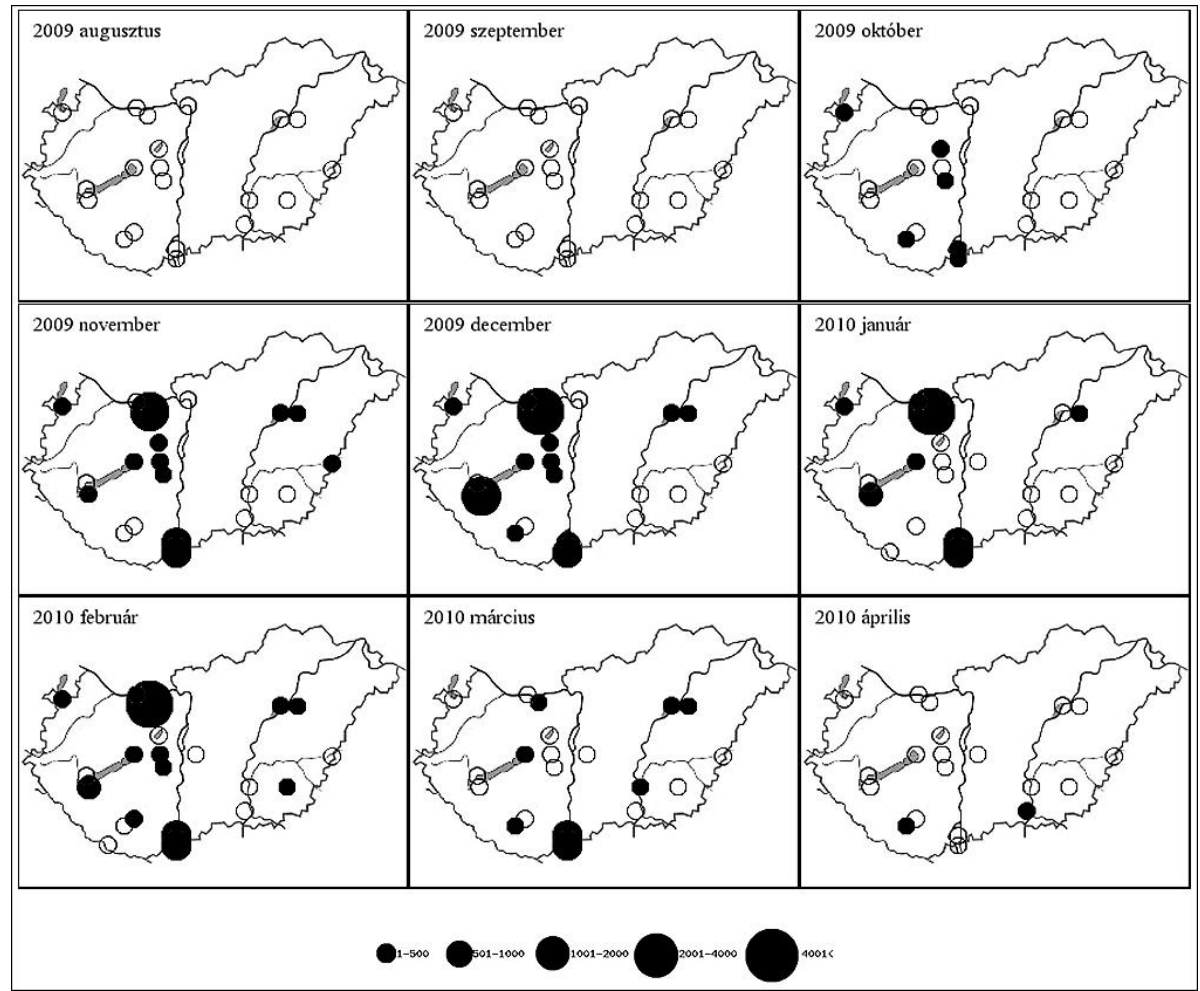

9. térkép: A vetési lúd előfordulás tér-idő mintázata Magyarországon 2009/2010-ben (FARAGÓ, 2011a).

Map 9: Spatial and temporal pattern of Bean Goose in Hungary, 2009/2010 (FARAGÓ, 2011a)

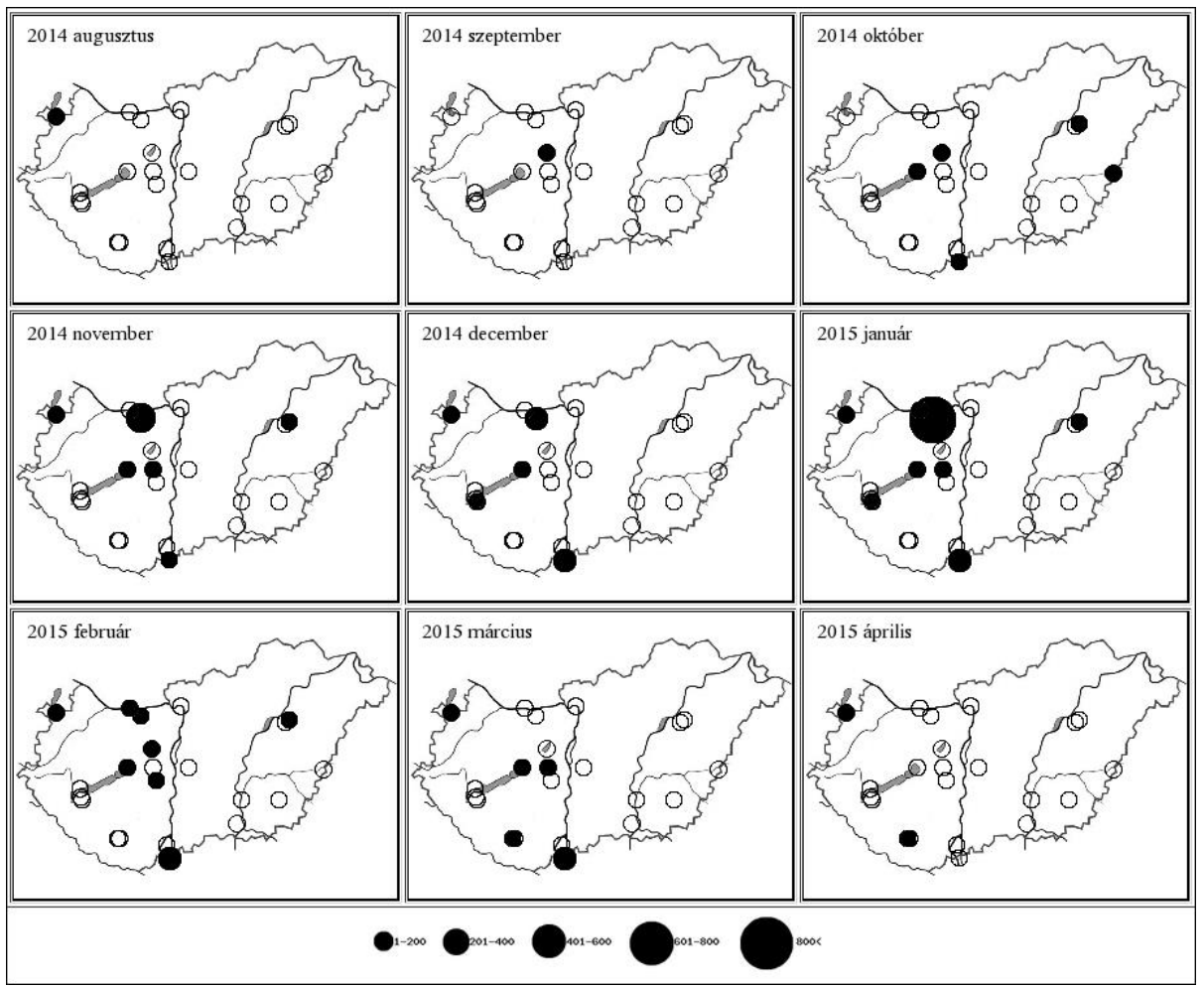

10. térkép: A vetési lúd előfordulás tér-idő mintázata Magyarországon 2014/2015-ben (FARAGÓ, 2016).

Map 10: Spatial and temporal pattern of Bean Goose in Hungary, 2014/2015 (FARAGÓ, 2016) 
A legnagyobb tömegek azokban az években a Fertő-tónál, a Balaton Ny-i medencéjében és a Kis-Balatonon, a Tatai Öreg-tónál, a Dinnyési Fertőnél és a Soponyai-halastavaknál vonultak át. Az utóbbi 15 évben drámai a faj hazai csökkenése, hiszen 2000-től már nem érte el tetőző egyedszáma az 50000 pld-t, 2012-től pedig a 10000 pld-t (FARAGÓ, 1995; FARAGÓ, 1996; 1997a; 1999a; 2010; 2015) (5-10. térkép). A legvalószínübb indok a Pannon-régióban telelő létszám csökkenésére a telelőterület nyugati irányú áthelyeződése lehet, mert - legalábbis magyarországi viszonylatban - sem a táplálkozási körülmények, sem a gyülekezőhelyek zavartsága, sem a vadászati hasznosítás mértéke nem indokolja ezt).

\subsection{VESZÉLYEZTETŐ ÉS KORLÁTOZÓ TÉNYEZŐK}

Az emberi tevékenységnek általában a vízivadra, illetve a vizes élöhelyekre gyakorolt kedvezőtlen hatásai az alábbiak (KALBE, 1981):

- vízi élőhelyek megszüntetése

- vízi élöhelyek beszükülése

- a zavarások növekedése

- a vízminőség romlása

- mérgező anyagok szabálytalan elhelyezése.

A negatív hatások közül először a legdrasztikusabbat, az élőhelyek megszüntetését kell említenünk. Sajnos a folyamszabályozások és lecsapolások óta már régóta fogynak természetes vizeink. A termőföldnyerés szándéka és az árvédelmi biztonság igénye vizes területeinket napjainkig terjedően redukálta. Különösen az intenzív mezőgazdálkodás meliorációs tevékenysége okozott nagy területveszteségeket a nedves gyepekben, kisebb vízállásokban. Az intenzív mütrágya és növényvédő-szer használat során, a kemikáliák bemosódása a felszíni és talajvizet egyaránt veszélyeztetik.

A természetes és mesterséges vizeink behatárolt kiterjedése, a természetvédelmi, vízügyi és halgazdálkodási korlátok nem mindig optimálisak a vízivad gazdálkodás számára. Mindenekelőtt szükséges a természetes, védett vizeink, az ahhoz kötődő növénytársulások, élőhely-komplexek megőrzése, fenntartása. Ennek biztosítása mellett mesterséges vizeink vízivad (vízimadár) eltartó képességét úgy kell fokoznunk, hogy abból a bölcs hasznosítás elve mellett fenntartható populációnagyságok minél nagyobbak, ezáltal a terítékek elfogadhatóak legyenek (FARAGÓ, 1997b).

Védelmét északi fészkelö-, vonuló-, pihenő-, táplálkozó és telelőhelyeinek együttes kíméletével, intenzív dúvadszabályozással, lehet segíteni.

Rajtunk kívülálló, általunk nem befolyásolható hatások a tundrai fészkelö területeken folytatott tájátalakítások (lecsapolások, folyószabályozások), zavaró tényezők (bányászat minden formája), iparosítás és annak minden környezetkárosító következménye, végül a fészkelö állomány (tavaszi/nyár eleji) vadászati hasznosítása. Ennek befolyásolása meghaladja kompetenciánkat, lehetőségeinket.

\subsubsection{A populáció sürüségét befolyásoló elsődleges paraméterek}

A természetes populációsűrüséget a termékenység, a halandóság illetőleg a be-és elvándorlás határozza meg a vetési lúd esetében is. A vadgazda feladata hogy a termékenység növekedését elősegítő faktorokat erősítse, a halandóságot növelöket pedig csökkentse, vagy felszámolja. 
A vetési lúd Magyarországon csak téli vendégként jelenik meg, így az elvándorlás csak a telelőterületek áthelyeződése formájában értelmezhetjük. E jelenségnek - lásd 1.3. fejezet - csak igen korlátozott mértékben van ellenszere. Amennyiben a telelöterület váltásának az okát nem a telelőterület ökológiai viszonyainak megváltozásában találjuk - s a vetési lúd esetében erről van szó - a terület eltartó-képességének növelésével nem lehet visszafordítani a jelenséget. A teljesség igényével rögzítenünk kell azt is, hogy a telelni érkező mennyiség csökkenése származhat a fészkelő állomány állományveszteségeiből is, ám ennek kimutatására nincs módunk, ugyanis a Pannon régióba érkező mennyiség kisebb, mint az az éves állományváltozási differencia, amely az alfaj mintegy 550000 példányos állományára jellemző lehet eltérő költési sikerü években.

A telelö, benne a Pannon régióba érkező populációt az élöhelyek (elsősorban táplálkozó helyek) meglétével, valamint spektrumuk kedvező alakításával támogathatjuk. Ugyanakkor a vonulásból adódóan előfordulhat alkalmasint a tundrai költőhelyek áthelyeződése, amelynek léptéke régiókat átívelő is lehet.

\section{A termékenységet}

(1) a táplálékforrás mennyisége és minősége, illetőleg

(2) a predátorok sürüsége korlátozza

(3) a telelés és a fészkelö-helyekre való visszavonulás során megszerzett, vagy elveszített kondíció határozhatja meg.

Az ezzel összefüggő halandóságot

(1) a táplálékforrás mennyisége és minősége,

(2) a predátorok zsákmányolása,

(3) a vonulásból adódó veszteségek (beleértve a vadászat okozta mortalitást),

(4) a téli/tavaszi kondícióromlás határozzák meg.

\subsubsection{A populáció sürüségét befolyásoló környezeti tényezők}

A vízimadár populációkra és közösségekre ható környezet főbb élettelen hatótényezői a klíma és a víz (hidrológiai viszonyok) közvetlenül és közvetve is hatnak a vízivad populációkra. A víz esetében annak mélységét, áramlási viszonyait, továbbá minőségét tarthatjuk valódi hatótényezőknek. Ez a vetési lúd esetében a telelöhelyek éjszakázó/pihenő területeinek megválasztása során bír jelentőséggel. A telelő vetési lúd populációk elhelyezkedésére a sekélyebb vizü területek kiterjedése és az általa biztosított nyugalom van hatással. A víz limnológiai paramétereinek gyakorlatilag nincs érdemi hatása.

A klímaelemek közül a hőmérsékletnek és a csapadéknak van kiemelt szerepe. A makroklíma mindenkori hatása a vízivad populációk aktuális elterjedését is megszabja. A vízimadárfajok zöme képes arra, hogy a negatív klímahatásokat - bizonyos korlátokkal migrációval, vagy vonulással kivédje, ellensúlyozza. A fény és a hőmérséklet meghatározza a vegetáció összetételét, produkcióját, ami a vízivad populációkra gyakorolt közvetett hatását mutatja (FARAGÓ, 1997b).

A domborzat a mikroreliefek (pl. szikesek), a partalakzat, iszappadok, iszapzónák és szigetek formációi révén közvetlenül is kifejti hatását, míg a talaj termőképessége a növényzeten keresztül közvetetten hat. A növényzet - mint az ökoszisztéma termelő része természetesen minden fogyasztó, így a vízivad fajok és a velük együtt élő más állatfajok létét is biztosítja. E vonatkozásban a magasabb rendủ vízi és parti vegetáció, illetve a szomszédos vagy távolabbi területek növényzete érdemel említést. A vetési lúd számára a növényzet először is azt a közeget (szubsztrátumot) biztosítja, amelyben élettevékenységét kifejtheti, ami a fedettség révén rejtőzködési lehetőséget, táplálkozó helyet kínál. 
A vízi, vízparti és szárazföldi növények hajtásai, levelei, rizómái, magvai táplálékul szolgálnak a vetési lúd számára. A koegzisztens állatfajok egyrészt predátorként (róka, egyes ragadozómadarak) vehetők figyelembe, mások, főként libafajok (nagy lilik, nyári lúd) pedig konkurensként (FARAGÓ, 1997b).

Mint ahogy az 1.2.3. Táplálkozás fejezetben láttuk, a vetési lúd a legadaptívabb fajként, a vonuló libák közül először ismerte fel a szántóterületek alternatív jelentőségét, $\mathrm{s}$ telelése során régóta élőhely váltással reagált arra. Ennek a jelenségnek a megfigyeléséből, felismeréséből származik a német Saatgans, magyar vetési lúd elnevezés. Ez az adaptivitás továbbterjedt a kezdetleges technikai adottságokkal bíró arató-cséplő gépek (kombájnok) felhasználásának elterjedésével az 1960-as években. E gépek esetében a nagy volt a betakarítási veszteség, ami jelentős mértékben megnövelte a táplálékkínálatot, $\mathrm{s}$ a nagy energiatartalmú, terimés kukoricaszemek nyújtotta megnövekedett telelési-táplálkozási lehetőség növelte a túlélést és a vonulás előtt zsírfelhalmozás lehetőségét. Kedvező lett továbbá a megnövekedett táblaméret és az egyes munkafázisokra fordított idő csökkenése, ami a telelési időszak kezdetén (október) és végén (március) jelentősen csökkentette a zavarást, ugyanakkor a gazdaságok nagyobb mérete miatt a gazdálkodók kevésbé reagálnak hevesen a megjelenő vadlúdcsapatok esetleges helyi kártételére.

Ahhoz, hogy vonuló/telelő vetési lúd populációnk állományfejlődését pozitív irányba befolyásolhassuk, elöször is elengedhetetlen a faj környezetigényének (föként a mértékadó faktorok optimumainak) megfelelő ismerete. A vízivad fajok környezetigénye sokféle, közülük azonban különösen két tényező emelhető ki az élőhely iránti igény és a táplálékigény (FARAGÓ, 2006b). A vízivad fajok bonyolult környezeti rendszer(ek)nek a tagjai. Az állatfajok rendelkeznek bizonyos adaptációs képességgel, mely lehetővé teszi számukra, hogy a környezet hatótényezői közül a számukra szükségeseket hasznosítsák, a közömböseket eltürjék, a károsakat pedig elkerüljék. 1997b):

A vízimadárfajok környezetigénye szerint többféle élőhelyre terjed ki (FARAGÓ,

- költőhelyek,

- táplálkozó helyek,

- pihenő- és éjszakázóhelyek,

- vedlöhelyek,

- telelőhelyek.

A vetési lúd esetében a költő- és vedlőhelyek a messzi tundrán találhatók, így annak tárgyalásától e helyütt eltekintünk, leszögezve, hogy ezen okból kívül esnek beavatkozási lehetőségeink területi tartományán.

A telelőhelyek vonatkozásában - mint azt az 1.2.4. fejezetben rögzítettük - a vetési ludak vonulása Európában egyrészt az Ibériai-félsziget és az Atlanti-óceán partvidéke, illetve a Pannon-régió felé irányul. Mindkét vonulási útvonalon érkező vetési ludak elérhetik a Pannon-régiót (az Atlanti-óceán partvidékére vonulók télközi köztes vonulással). Megismételjük tehát: a Pannon-régió - amelybe hazánk is beletartozik - potenciálisan a vetési lúd egyik legfontosabb vonuló és telelő területe.

A telelö, pihenő és éjszakázó helyek Pannon régióbeli elhelyezkedését illetően a korábbi vizsgálatok (STERBETZ 1983, FARAGÓ 1995) is kimutatták, hogy a vetési lúd elsősorban a „Dunántúl libája” volt. Öszi tetőzése során legnagyobb egyedszámban a KisBalatonon, a Velencei-tónál és Dinnyési Fertőnél, a Soponyai-halastavaknál, a Tatai Öregtónál, a Fertő tónál, a Balatonnál, és a Duna gemenci és bédai/karapancsai szakaszán jelentek meg. A telelö állományok esetében, ugyanezeken a területeken lehetett a legnagyobb egyedszámban megfigyelni. Alkalmanként azonban - a nagy lilikek egyedszám növekedésével együtt - a Hortobágyon is tetemes mennyiség jelenhetett meg. A tavaszi 
időszakban a Velencei-tónál és Dinnyési Fertőnél, a Soponyai-halastavaknál, a Tatai Öregtónál, a Fertő tónál és a Kis-Balatonnál tartanak ki a legnagyobb mennyiségben, $\mathrm{s}$ a Hortobágy is fontos állomáshelye. A telelés során kimutatható volt egy Fertő tó-Kis-BalatonBalaton nyugati medencéje-Dráva-mente, illetőleg a Tatai Öreg-tó-Velencei-tó-Dinnyései Fertő-Soponyai-halastavak-Balaton keleti medencéje-Duna alsó szakasza területláncolatok közötti szoros kapcsolat és területváltás (FARAGÓ \& PELLINGER 2009).

A vetési lúd táplálkozó helyei a telelőterületein a mezőgazdasági kultúrákra koncentrálnak. A Fertő-tónál végzett vizsgálatok szerint a vetési lúd éjszakázó- és táplálkozó területei között olykor 50-100 km-es távolság is lehetett, ami tulajdonképpen megegyezik a Kisalföld területhatáraival (FARAGÓ 1994). A kirepülés távolsága függött a táplálkozó helyek táplálékkínálatától. Ha közel voltak gazdag kínálatú táplálkozó-területek, akkor a libák a hajnali kihúzás után a délelött folyamán visszarepültek a tóra, ott ittak és pihentek, majd kora délután ismét kihúztak táplálkozni és napnyugta után tértek meg éjszakázni. Ha csak nagyobb távolságra voltak elérhető táplálkozó területek, akkor a napközbeni visszahúzás elmaradt. Abban az esetben, ha hideg időszakban, nagy távolságban találnak a libák táplálékot (pl. kukorica tarlót) az is előfordulhatott, hogy éjszakázni sem tértek vissza a tóra. Ez esetben vízszükségletüket a hó csipegetésével fedezték, biztonságérzetüket pedig a nagy táblák közepére való településsel fokozták. A kihúzó libák táplálkozó-helyként elsősorban a gabonavetéseket, a kukorica tarlót, a repcét, ritkán a szántásokat, a cukorrépa- és napraforgótarlókat részesítették elönyben (FARAGÓ 2002).

\subsubsection{A vetési lúd állományt veszélyeztető tényezők összefoglalása}

Az európai viszonyok között a vízivad szempontjából kulcsfontosságú, a kontinens belsejében elhelyezkedő vizes élőhelyeken fellépő veszélyeztető tényezőket TUCKER \& EVANS (1997) 17 típusba sorolták. A felsorolás egyben azt is mutatta, hogy az egyes veszélyeztető tényezők a vizes élőhelyek teljes fajkészletét milyen arányban érintik, azaz melyek a súlypontos és kevésbé súlypontos kérdések. A hazai vízivad fajokra hasonló elemzés részben az idézett munka, részben a hazai vizsgálati eredmények alapján készült (FARAGÓ, 2006b). A veszélyeztető tényezők rangsora eszerint az alábbi (valamennyi vizsgált faj - N=43 érintettségi \%-ában), benne vastag és dőlt betűvel kiemelve a vetési lúd szempontjából kiemelten jelentős tényezőkkel.

- Lecsapolás és termőföldnyerés $65 \%$

- Part menti élőhelyek elpusztítása (mezőgazdasági célokra, árvízvédelem miatt) $65 \%$

- Vadászat 58\%

- A turizmus fejlesztése és más rekreációs tevékenység 56\%

- Szennyezés mérgező anyagok által 51\%

- Tápanyagszennyezés (eutrofizáció, hipertrofizáció) 47\%

- Kereskedelmi célú halászat és sporthorgászat $35 \%$

- A vízszint szabályozása $30 \%$

- A vegetáció helytelen kezelése $28 \%$

- Természetes vizes területek felduzzasztása (gátak, stb.) $26 \%$

- A predátorok állománynövekedése $26 \%$

- Savasodás (légköri szennyeződéstől = savas eső) $23 \%$

- Túlzott vízkivétel és a vízgyüjtő területek közötti víztranszferek $21 \%$

- Túlzott üledék felhalmozódás $14 \%$

- Aquakultúrák 14\% 
- Csatornázás $9 \%$

- Idegenhonos (nem őshonos) fajok betelepítése 9\%

Mindezek alapján a vadvédelem feladata a negatívan ható tényezők (részbeni) eliminálására, vagy hatásaik csökkentésére kell irányulnia.

\subsection{A VÉDELMI GYAKORLAT ÉRTÉKELÉSE}

\subsection{1. Élőhelyvédelem és területkezelés}

A vízivad élőhelyvédelem hazai gyakorlata több elemből áll. Az első az országos jelentőségü védett területek, amelyeknél a védetté nyilvánításnak elsődleges, vagy legalábbis fontos szempontja volt a vizes élőhelyek, illetve a vízimadarak (vízivad) védelme. E területeken a természetvédelem, már a védettség passzív védelmi funkciójának beteljesítésével is jelentős eredményeket ért el. A védettség után megfogalmazott konkrét kezelési tervekben a megörzés biztosított, és alapja a majdani aktív beavatkozásoknak, a rekonstrukcióknak. Az élőhelyvédelem következő fázisa a Ramsari területek kijelölése volt, amelynek eredményeként jelenleg 29 terület tartozik e körbe, összesen 243 410,6 ha-on (FÖLDMÜVELÉSÜGYI MINISZTÉRIUM, 2015). Magyarország EU csatlakozása révén kijelölésre kerületek az Európai Jelentöségü Madárélőhelyek (IBA), majd a Madárvédelmi Irányelv célkitüzései szerint a Különleges Madárvédelmi Területek (KMT)(special protection area SPA).

A vízivad védelmének egyik kulcskérdése a nyugalom biztosítása. Ezért a vízivad fészkelése és vonulása szempontjából nemzetközi jelentőségü és hazai kiemelt jelentőségü vízi élőhelyeken a vadászati hatóság - védett természeti területet, illetve NATURA 2000 területet illetően a természetvédelmi hatóság szakhatósági hozzájárulásával - szabályozza a vizivad vadászat rendjét. Ebben meghatározza a vízivad vadászatának helyét, módját, idejét, gyakoriságát. Ezek az úgynevezett vízivad kíméleti területek.

$\mathrm{Az}$ emberi tevékenységnek a vízivadra, illetve a vizes élöhelyekre gyakorolt hatása negatív és pozitív egyaránt lehet. A negatív hatásokat a 1.4. Veszélyeztetö és korlátozó tényezök fejezet tárgyalja. A pozitív hatások között vannak a fajra és közösségekre közvetetten és közvetve ható ténykedések:

- új vizes élőhelyek létrejötte, nem elsődlegesen vízimadarak, vízivad számára kialakítva;

- meglévő vizes élőhelyeink, élőhely-komplexeink megőrzése, fenntartása;

- vizes élőhelyek rekonstrukciója;

- vizes élőhelyek átalakítása vízivad, vízimadarak számára.

A vízgazdálkodási szempontú vízépítési munkák során sok olyan csatorna, tározó jött létre, amelyek a későbbiekben a vízivad számára is alkalmas élőhelyekké váltak, vagy térségük környezeti feltételei elönyösen alakultak. E kategóriába sorolhatjuk a mesterséges, alföldi jellegü halastavainkat is, amelyekböl a vízjogi nyilvántartások szerint 277 van. E tórendszerek nagy része $(156 \mathrm{db}) 10$ és 100 hektár közötti, csupán 10 tórendszer nagyobb 500 hektárnál. A halastavak összterülete mintegy 30100 hektár (NAGY \& KÖNCZEY, 1995). Ez az érték lényegében nem változott az elmúlt 20 évben, legfeljebb a hasznosítás intenzitásában következett be csökkenés. (A KSH, STADAT művelési ág szerinti nyilvántartása szerint a halastavak területe 2015-ben 36439 hektár volt.)

A halastavak - a természetes vízállások kis területi kiterjedése miatt - mind a vadgazdálkodás, mind a természetvédelem számára igen nagy jelentőségüek. Közülük több 
halastórendszer egy, vagy több faj megjelenő mennyisége alapján besorolható a nemzetközileg is számon tartott és védelemre érdemesítendő kategóriába (FARAGÓ 2006b).

A víztározók kialakulása (Soponya, Kis-Balaton, Tisza-tó stb.) ugyancsak új lehetőségeket teremtett a vadludak, így a vetési lúd vonulása (nem mellesleg a nyári lúd fészkelése) szempontjából is.

A természetes és mesterséges vizeink behatárolt kiterjedése, a természetvédelmi, vízügyi és halgazdálkodási korlátok nem mindig optimálisak a vízivad gazdálkodás számára. Mindenekelőtt szükséges a természetes, védett vizeink, az ahhoz kötődő növénytársulások, élőhely-komplexek megőrzése, fenntartása. Ennek biztosítása mellett mesterséges vizeink vízivad (vízimadár) eltartó képességét úgy kell fokoznunk, hogy abból a bölcs hasznosítás elve mellett fenntartható populációnagyságok minél nagyobbak, ezáltal a terítékek elfogadhatóak legyenek (FARAGÓ, 2006b).

A vízivad populációk fenntartásához mindenekelött vizes élöhely hálózatra van szükség, azaz a „tipegö kö” funkciójú vizes élöhely hálózat kialakítására és fenntartására. A hálózat tagjainak alapismérvei a nyugalom, a diverz élőhely szerkezetet feltételező kedvezö táplálékellátottság. Hazai vizes élőhelyeink trofitása, azon keresztül a vízivad számára biztosított táplálék forrás kínálata magas, különösen a sekélyvizü víztípusokban (leginkább a halastavakban és tározókban). A nyugalmat pedig a vízivad kíméleti területek biztosítják, amelyek maguk is megfelelnek az elöző kritériumoknak.

A vízivad kíméleti területek hálózatának - azaz egy általános ökológiai biztonságot jelentő vizes élőhely hálónak a vadászati korlátozást messze felülmúló szerepe is van a jövőben. Az ok pedig a globális klímaváltozás következményei, amelyekre fel kell készülni a vizivad védelem vonatkozásában azért, hogy lehessen majd akkor is a vízivaddal gazdálkodni is, s annak keretében vadászni is rá (FARAGÓ, 2006b).

Az élőhelyvédelem gyakorlatában kétféle megközelítés létezik: passzív és aktív. Míg az elöbbinél nincs beavatkozás, addig az utóbbi a beavatkozások szerint lehet: az élöhelyek rekonstrukciója, kialakítása (átalakítással, létesítéssel) vagy a gazdálkodás befolyásolása (FARAGÓ, 1997b; STANDOVÁR \& PRIMACK, 2001).

Az ezredforduló környékére összesítve több mint 70 területen és közel 55 ezer hektáron valósult meg vizesélőhely-rekonstrukció Magyarországon (LOTZ, 1988; MAGYARICS et al., 1999; TARDY et al., 2007;). Ezt követöen az operatív programokból (pl. KEOP), LIFE stb. pályázatokból közel száz kisebb-nagyobb projekt valósult meg országszerte, amelyek rendkívül hasznosak a vízivad populációk szempontjából. Bár kiterjedésüket tekintve összességében az ország 1\%-át, a védett területek 10\%-át sem érik el, mégis a legértékesebb élőhelyek közé tartoznak, egyben a magyar természetvédelem sikertörténetei.

Az élőhelyvédelem esetében kiemelten fontos a zavartalanság, a nyugalom biztosítása. Bármilyen kiválóak is az élőhely környezeti adottságai, ha a területen folyamatos emberi zavarás hatása alatt áll a vízivad állomány, a környezeti paraméterek elönyös adottságai nem tudnak érvényesülni (FARAGÓ, 2006b).

\subsection{2. Állományvédelem}

Állományalakulására a vadászati hasznosítás van - közvetlen és közvetett módon - negatív hatással. A magyar vadászati jogszabály felsorolja azon vizes területeket, ahol nem lehet ólomsöréttel vadászni. Magyarországon elsősorban a telelő populációk védelmét kell szorgalmaznunk. Mivel vízhez kötődő faj, bármely vizes élőhely, de különösen az éjszakázóhelyek kímélete jelentőséggel bír. A szárnyas és szőrmés predátorok szerepe e faj esetében lokális lehet, leginkább elhanyagolható. 
A vetési lúd vadászható faj Magyarországon, vadgazdálkodási értéke $20000 \mathrm{Ft}$. Vadászati idénye október 1.-január 31 között került meghatározásra, naponta, személyenként legfeljebb 6 példány ejthető el.

További megkötés, hogy a vetési lúd vadászati idénye Hajdú-Bihar, Békés és Csongrád megye teljes közigazgatási területén, valamint Jász-Nagykun-Szolnok megye tiszántúli területén december 1-jén kezdődik és január 31-ig tart, amelynek alapvető indoka a globálisan veszélyeztetett vonuló és telelö kis lilikek (Anser erythropus) tévedésen alapuló lelövésének megelőzése volt.

Faji szintü teríték nyilvántartásáról első ízben 8/1993. FM sz. rendelet rendelkezett, így 1994-től állnak rendelkezésre adatok (4. ábra). Terítéke az elmúlt 20 esztendőben hasonlóan a számlált mennyiséghez - jelentős visszaesést mutatott. 1994-ben 6071 pld, 2000ben 4389 pld, 2005-ben 2681 pld, 2010-ben 3063 pld, 2011-ben 3430 pld, 2012-ben 2100 pld, 2013-ban 1724 pld, 2014-ben 1180 pld volt (CSÁNYI 1996; CSÁNYi 2001; CSÁNYI et al. 2006, 2012a; 2012b, 2012c, 2014, CSÁNYI 2015).

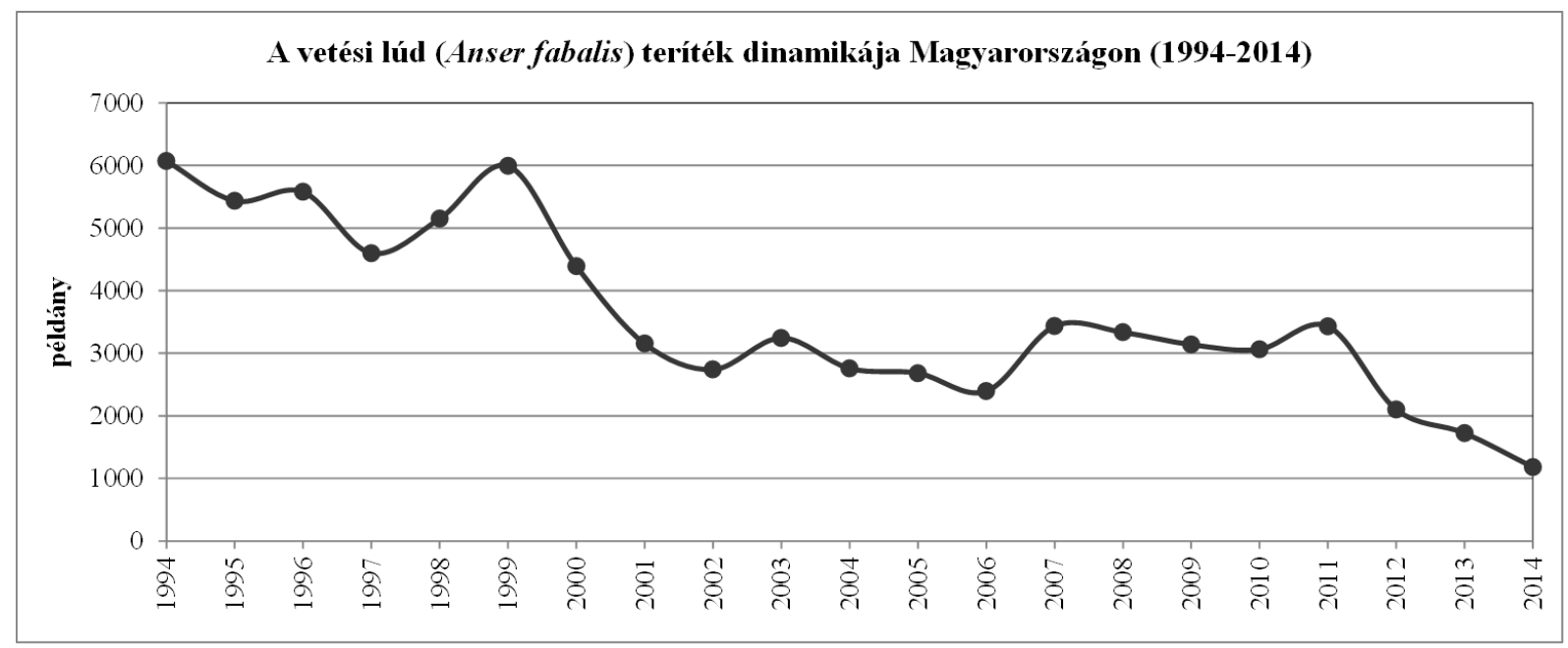

4. ábra: A vetési lúd terítékének alakulása 1994-2014 között Magyarországon (OVA adatai alapján)

Figure 4: Bag dynamics of Bean Goose in Hungary between 1994 and 2014(after Hungarian Game Management Data Base)

Ha hozzátesszük azon ismeretünket (lásd 1.5. fejezet), amely szerint a vetési lúd az Alföldön alig és emellett csökkenő példányszámban fordul elő, a terítéknek pedig jelentős részét onnan jelentik (5-7. térkép), akkor valószínüsíthető, hogy az Alföldről jelentett vetési ludaknak a nagy része nagy lilik lehet. Ilyen megközelítésben a faj terítéke bizonyosan 1000 pld alá csökkent.

\section{CSELEKVÉSI TERV}

\subsection{CÉLKITÜZÉS}

A vetési lúd Magyarországon (általában a Pannon régióban) vonuló és telelő állománya az elmúlt két évtizedben folyamatosan csökkent.

A rövid és hosszú távú cél a stabil populáció fenntartása, esetlegesen növelése, bár utóbbira - lásd állománycsökkenés kiváltó okai - csak korlátozott mértékben van lehetőség. 


\subsection{FELADATOK}

\subsection{1. Állománynövelés vad populációkra alapozva}

Mivel a vetési lúd nem költő faj Magyarországon, a tundrai környezetben fészkelő faj költőállományainak védelme kívül esik területünkön, az kizárólag Oroszországban oldható meg. A hozzánk érkező telelő populációt élőhely-gazdálkodással, az élőhelyek védelmével, fejlesztésével és nem utolsósorban felelős hasznosítással tudjuk támogatni. A minden faj esetében végső megoldásként felmerülő tenyésztés és kibocsátás a vetési lúd esetében nem alkalmazható módszer.

\subsection{2. Élőhelygazdálkodás}

A vízivad populációkra, így a vetési lúdra is sok tényező van hatással, ami jelentősen befolyásolja a faj jelenlétét, illetve állománynagyságát. A környezeti tényezők közül a klímára gyakorlatilag nincs ráhatásunk, a klímaváltozás hatásaira, illetve az arra adható válaszokra nem csak országos, hanem globális válaszok adandók, így az meghaladja lehetőségeink körét. Egy másik fontos környezeti tényező, a víz, ami viszont mennyiségében (és minőségében is) befolyásolható, így megfelelő vízgazdálkodással, vízkormányzással jelentős eredmények érhetők el, ugyanakkor ennek ellentéteként komoly károk is okozhatóak.

A biotikus faktorok közül fontos szerepe van az élöhely szerkezetének, a rendelkezésre álló pihenő, éjszakázó és táplálkozó területek kiterjedésének, amelyek megőrzése, kímélete, nyugalmának biztosítása lényeges feladat. Jelentős el- és megtartó szerepe van a táplálékforrásnak, annak minőségének és mennyiségének, ami megfelelő (mező)gazdálkodással szintén pozitívan befolyásolható. További alapvető kérdés a predációs nyomás mértéke - bár a kizárólag telelő vetési lúd esetében annak jelentősége erősen korlátos -, illetve annak szabályozása. Emellett az egyéb zavarás mértéke, beleértve az antropogén hatásokat is csökkentendö.

A telelő vetési lúd állomány fenntartása céljából többféle élőhely-gazdálkodási lehetőséggel élhetünk, amelynek alapja az a tény, hogy a megfelelő élőhelykezelés egyaránt érdeke a vadgazdálkodásnak és a természetvédelemnek. A vetési lúd (s általában a vadlúd) populációk védelemének számos addicionális haszna van más védett, illetve fokozottan védett faj, főként az átvonuló és telelő, vadászható és védett vízimadarak vonatkozásában.

\subsubsection{A meglévő élőhelyek kímélete}

Ha egy terület jó vetési lúd állománnyal rendelkezik a téli félév (vonulás és telelés) során, akkor az élőhelyvédelem egyik legegyszerübb módja, ha területen nem teszünk semmi helyrehozhatatlant, megörizzük mindazt, ami már rendelkezésre áll, s összhatásával eddig is vonzotta a fajt.

A vetési lúd hazánkban a természetes és mesterséges vizes élőhelyeken egyaránt megjelenik. A természetes, vagy természetközeli élőhelyeken, illetve ahol nem folyik gazdálkodás az élőhelyek védelme a vadgazdálkodás és a természetvédelem közös feladata. Amennyiben a vizes élőhelyen gazdálkodás (halászat, nádgazdálkodás), vagy más területhasznosítás folyik, ott szükséges a gazdálkodóval, a terület kezelőjével való együttmüködés.

A halastavak jelentős élőhelyek, ahol a gazdálkodás során több probléma adódhat. A vetési lúd érdekében a következőket mindenképpen figyelembe kell venni:

- A nádasok, nádszegélyek védelme érdekében a nádgazdálkodás során térbeli és időbeli korlátozásokat kell alkalmazni. 
- A téli időszakban a fagyott tavakon célszerü nyílt vízfelületet (lihogót) tartani, ami koncentrálja a vízimadarakat.

- A vízimadarak (kiemelkedően a kárókatona) által halban okozott károk megelőzése, illetve csökkentése érdekében végzett riasztások és kilövések csak a szükséges mértékben történjenek, amivel az éjszakázó helyek kíméletét érhetjük el.

- Azokon a területeken, ahol a horgászat és a turizmus a hasznosítás részét képezi, területi korlátozással biztosítható a pihenőhely funkció.

Az eredményes élőhelyvédelem egyik alapja a nyugalom biztosítása. Ennek hiányában nem juthatnak érvényre a kedvezö környezeti adottságok. Mivel a vadászati hasznosítás igen nagy nyomást jelent, ezért érdemes a vadászterületeken időbeli és térbeli korlátozásokat együtt, vagy külön-külön alkalmazni.

A vizes élőhelyek melletti, vagy azok közelében lévő táplálkozó területeken, gyepeken és szántóterületeken extenzív gazdálkodást kell alkalmazni. Az ősz végi és téli időszakban a kukoricatarlók fenntartásával, a tarlóhántás elhagyásával vagy késleltetésével segíthetők a vonuló és telelő állományok.

Az élöhelyek védelme, kímélete elsősorban ésszerüséget kíván, sok esetben alig kerül pénzbe, ugyanakkor rendkívül eredményes lehet.

Jelentőség: Nagy (8-10)

Hatékonyság: Közepes (7)

Érintett állománynagyság: $100 \%$

Ütemezés: Folyamatos

Felelős: Földmüvelésügyi Minisztérium, Megyei Kormányhivatalok

Együttműködő: halgazdálkodók, halászati érdekképviseleti szervek, OMVV, OMVK, vadgazdálkodók, nemzeti parkok,

\subsubsection{2. Élőhelyfejlesztés}

Az állománynövelés potenciálisan leghatékonyabb módja az élőhelyfejlesztés lehet. Természetesen nemcsak meglévő élőhelyek fejleszthetők, hanem degradált területeken élőhely-rekonstrukciók vagy akár új élőhelyek létesítése is igen eredményesek lehetnek. A vetési lúd esetében is sikeres lehet a nyári lúd érdekében ANDREWS \& KINSMAN (1990) által ajánlott megoldások:

- Az élőhelyfejlesztés során nagy kiterjedésü vízfelületet kell létrehozni. Természetesen néhány hektár is jelentős eredményt hozhat, főként ha ezekből sok van, de a minimálisan a több tíz hektáros területek hozadéka értelemszerüen jelentösebb.

- A vízmélység a terület jelentős részén sekély legyen.

- A partvonal jelentős részének kialakítása lankás (1:10) rézsűvel történjen.

- Szélvédett rövidfüvü, vagy csupasz felszínü pihenőhelyeket kell kialakítani.

- Változatos vízinövényzetet (emerz és parti vegetáció) kell kialakítani.

- A vizes élőhely mellett legyenek nedves gyepek és extenzíven kezelt területek (gyepek, mezőgazdasági területek).

A fenti ajánlások közül egy-egy önmagában is számottevő segítséget jelent. A nyári lúd érdekében elvégzett élőhelyfejlesztés természetesen más vízivad fajok számára is kedvező, ezért nemcsak vadgazdálkodási, hanem természetvédelmi szempontból is kívánatos. Az igazsághoz hozzátartozik, hogy ilyen új területek létesítése sok nehézségbe ütközik. 
Jelentőség: Nagy (8-10)

Hatékonyság: Magas (9-10)

Érintett állománynagyság: 100\%

Ütemezés: Folyamatos

Felelős: Földművelésügyi Minisztérium, Megyei Kormányhivatalok - vadászati felügyelet

Együttműködő: mezőgazdasági érdekképviseleti szervek, OMVV, OMVK, gazdálkodók, nemzeti parkok

\subsubsection{Dúvad-gazdálkodás}

A klasszikus apróvad-gazdálkodás gyakorlatában a legnagyobb hangsúlyt a dúvadgyérítésre helyezték. Ez nem véletlen, hiszen korábban az élöhely minőségének romlása még nem volt meghatározó probléma. Napjainkban Nyugat-Európában valamennyi apróvad szakértő az élőhely minősége mellett az első helyen említi a dúvad fajok szerepét az apróvad populációk szabályozásában. Mindenütt más és más fajokra helyezik a hangsúlyt, hiszen állatföldrajzi és ökológiai okokból másoknak jut a szabályozó szerep. Ezért is célszerü a régóta használt dúvad kifejezés alkalmazása, amely a legközérthetőbb és a magyar szaknyelvben gyökerező, összefoglaló neve azon ragadozó madaraknak, varjúféléknek és emlősöknek, amelyekről a külföldi szakirodalom, mint szabályozható predátorokról beszél. A dúvad fogalomnak napjainkban tehát olyan tartalma is van, amely e fajok gyérithetöségére, azaz nem védett voltára utal, tehát a mindenkori jogszabályok határozzák meg az e körbe sorolandó fajokat.

A külföldön folytatott vizsgálatok eredményeit tehát nem lehet általánosítani, s különösen nem lehet a hazai viszonyokra kritika nélkül alkalmazni, leghelyesebb, ha a hazai vizsgálatokra alapozzuk megállapításainkat (lásd LANSZKI, 2002; HELTAI, 2010; LANSZKI, 2012). Egyedüli közös alapelv van - amit tudatosítani kell - az, hogy hatékony dúvadszabályozás nélkül nincs eredményes vízivad-gazdálkodás.

Ha egy adott területen növekszik a lúdállomány nagysága, értelemszerüen a predátorok állománysürüsége is növekszik. Az élőhelyfejlesztés emiatt kizárólag dúvadgyérités mellett eredményes. A vetési lúd vadászható ellenségei közül kizárólag a róka említendő meg, a védett fajok közül a rétisas (Haliaeetus albicilla) zsákmányolása lehet említést érdemlő. Egyéb szőrmés és szárnyas predátor fajok esetében a mindenkori vadászati, illetve természetvédelmi jogszabályoknak megfelelően kell eljárni. Azon esetekben, amikor fokozottan védett, veszélyeztetett faj okoz az elviselhetőnél nagyobb veszteségeket, azt el kell viselni.

Legfontosabb feladat azonban a szőrmés ragadozók állományainak csökkentése, amelyet főként csapdák alkalmazására alapozottan lehet kellő hatékonysággal elvégezni. Hazánk EU csatlakozását megelőzően a csapdázás törvényes lehetőségei igen korlátozottak voltak, amelyet jól tükröz HELTAI \& SzEMETHY (2000) ragadozógazdálkodásról szóló tanulmánya. A nemzeti szabályozás közösségi joggal történő harmonizációja következtében azonban számos új eszköz és módszer kipróbálására és gyakorlatban történő elterjesztésére nyílt lehetőség. A vonatkozó nemzetközi egyezmények, valamint a közösségi jogszabályok a tiltott eszközök és módszerek pontos meghatározása mellett - tág teret engednek a csapdahasználatnak. FARKAS (2009) és HAJAS (2011, 2013) egymástól függetlenül végzett kísérletei igazolták, hogy kellő szakértelem esetén lehetséges bizonyos ölőcsapdák (például a hattyúnyak, vagy a forgókapcsos testszorító csapdák) szelektív használata. Ahol az ölőcsapdák használata különböző okokból adódóan kerülendő, hatékony alternatívát jelenthet helyettesítésük modern visszatartó kábeles csapdákkal (HAJAS 2012, 2013).

A csapdázásra alapozott ragadozógazdálkodás számára fontos kihívást jelent, hogy 2016 júliusától kezdődően az illetékes hatóságoknak gondoskodniuk kell majd a nemzetközi 
kíméletes csapdázási szabványokról szóló nemzetközi megállapodásban foglalt előírások maradéktalan betartatásáról.

A hatékony dúvadgazdálkodás esetében is elmondható, hogy más vízivad fajok számára is kedvező, ezért nemcsak vadgazdálkodási, hanem természetvédelmi szempontból is hasznos.

Jelentőség: Magas (8-10)

Hatékonyság: Közepes (6)

Érintett állománynagyság: 100\%

Ütemezés: Őszi, vonulási időszak előtt, évente ismételve

Felelős: Földművelési Minisztérium, Megyei Kormányhivatalok, NymE Vadgazdálkodási és Gerinces Állattani Intézet, Magyar Csapdázók Egyesülete

Együttmüködők: hivatásos és sportvadászok, mezőőrök, természetvédelmi őrök

\subsubsection{Politika és jogalkotás}

A vízivad esetében számos védelmi eszköz áll rendelkezésre mind jogi, mind az ez alapján megvalósult fizikai (területi) értelemben (védett természeti területek, Ramsari területek, Natura 2000 Különleges Madárvédelmi Területek - SPA, Fontos madárélőhelyek - IBA, vízivad kíméleti területek). Ezek fenntartása kulcsfontosságú, hiszen hosszú távon is bebizonyosodott szerepük. Szüken véve a vetési lúd védelmével kapcsolatban jelenleg nincs olyan szükséglet, ami külön jogi szabályozást igényelne. Mindazonáltal figyelemmel kell kísérni a fészkelő és a vonuló-telelő populáció állományváltozását.

Szorgalmazni kell a vadászatok során más nem vadászható vízimadárfajok kíméletét, a halgazdálkodók által végzett kárókatona-gyérítések során a lúdfajok és más vízimadárfajok kíméletét.

A politikai döntéshozás, a vidékfejlesztési programok és a természetvédelmi stratégiák, koncepciók során előtérbe kell helyezni az élőhelyfejlesztések és a vizes élőhelyek rekonstrukciójának támogatását. Erre az európai uniós operatív programok keretében jelentős források biztosíthatók.

Mivel a vetési lúd esetében (de más lúdfajoknál is) a vizes élőhelyek melletti szárazföldi (nem vízi) növényzet és a mezőgazdasági területek jelentős szerepet játszanak föként a táplálkozás tekintetében, ezért ezeken a helyeken - az európai tendenciákkal összhangban - az agrárpolitikának olyan irányt kell képviselnie, amely hagyományos földhasználati eljárásokat előtérbe helyezi, illetve szorgalmazza a füves puszták illetve a természetes gyepterületek fennmaradását. A korábban intenzív művelésű szántó élőhelyek esetében a mezőgazdasági politikának és a törvénykezésnek mellőzni kell az intenzív termelésnek és eszközrendszerének (komplex melioráció, öntözőrendszerek kialakítása, erdősítés) további támogatását. Mindezekkel szemben támogatnia kell a pihentetett területekkel (set-aside) jellemezhető gazdálkodási gyakorlatot, a tartós földbérleti és földvásárlási programokat, az extenzív gazdálkodást.

A vetési lúd legfontosabb pihenő-/éjszakázó helyei országos vagy helyi védelem alatt állnak és túlnyomó többségük vonatkozásában vízivad vadászati korlátozások is érvényben vannak (lásd 1.7.1. fejezet). Kiemelten fontos ennek a statusquo-nak fenntartása, illetve a még hiányzó természetvédelmi kezelési tervek (pl. Öreg-tó) elkészíttetése, amelyek a szabályozás fontos eszközei.

Jelentőség: Nagy (8-10)

Hatékonyság: Közepes (6)

Érintett állománynagyság: 100\% 
Ütemezés: Folyamatos

Felelős: Földművelésügyi Minisztérium, Megyei Kormányhivatalok

Együttmüködő: nemzeti parkok, OMVV, OMVK

\subsubsection{Tanácsadás földtulajdonosok és vadgazdálkodók számára}

Fontos a folyamatos és rendszeres kapcsolattartás a tulajdonosokkal, a területhasználókkal és vadgazdálkodókkal. Minden lehetséges módon (információs füzetek, plakát, média, személyes csoportos találkozók és egyéni kapcsolatok) meg kell ismertetni a gazdálkodókkal a vetési lúd helyzetét, a vadvédelem lehetséges módjait, az érintettek közös érdeken alapuló részvételi lehetőségét (földhasználat, élőhelyvédelem, dúvadgyérítés) a védelmi munkában. Tanácsadással és pályázati lehetőségek felkutatásával segíteni kell a vízivadas területeken az élőhelyfejlesztéseket, élőhely-rekonstrukciókat, extenzív gazdálkodási módokat, különös tekintettel a várható környezetgazdálkodási programok keretein belül megvalósítható pályázatokra, fejlesztési lehetőségekre. Különösen fontos az együttmüködés a földtulajdonosokkal, gazdálkodókkal a vetési lúd által okozott mezőgazdasági károk vizsgálata tekintetében. Olyan egzakt vizsgálatok végzendők, amelyek mind tudományos szempontból, mind gazdálkodási és problémakezelési oldalról valódi megoldást nyújtanak és alapjai lehetnek további támogatási rendszereknek (ld. Magas Természeti Értékủ Területek rendszere).

Jelentőség: Magas (8-10)

Hatékonyság: Közepes (6)

Ütemezés: Őszi, vonulási időszak előtt, évente ismételve

Felelős: Kormányhivatalok

Együttmüködők: vadgazdálkodók, Nemzeti Agrárgazdasági Kamara megyei szervezetei, Társadalmi Természetvédelmi Szolgálat területi szervezetei

\subsubsection{Oktatás és továbbképzés}

A vízivad védelmére, általában a gazdálkodásra vonatkozó ismeretek oktatása és az ismeretek folyamatos aktualizálása fontos az alap-, közép- és felsőfokú vadgazdálkodási (és természetvédelmi) szakemberképzésben. Az oktatást végző intézmények tananyagai, tankönyvei és jegyzetei tartalmazzák a gazdálkodás elméleti és gyakorlati ismeretanyagát. A vadgazdálkodási szakemberek rendszeres továbbképzései során ugyancsak ismertetni kell a védelem és gazdálkodás célkitüzéseit, módszereit és eredményeit.

Jelentőség: Magas (8-10)

Hatékonyság: Közepes (6)

Ütemezés: Folyamatosan

Felelős: OMVV, OMVK országos és megyei területi szervezetei, NymE Vadgazdálkodási és Gerinces Állattani Intézet

Együttműködő: szakirányú képzést folytató alap-, közép- és felsőfokú oktatási intézmények

\subsubsection{Nemzetközi együttmüködés}

A vízimadarak védelmét és kutatását nemzetközi szinten a BIRDLIFE INTERNATIONAL és a WETLANDS INTERNATIONAL koordinálja, ezen belül a libákkal, így a vetési lúddal a GoOSE SPECIALIST GROUP foglalkozik. Magyarországon vízivad, így a vetési lúd állományának monitorozását a MAGYAR VízIVAD MONITORING keretében a Nyugat-magyarországi 
Egyetemen a Vadgazdálkodási és Gerinces Állattani Intézete szervezi 1984 óta folyamatosan (FARAGÓ, 1996). Ennek keretében a hazai adatok a Nemzetközi Vízimadár Számlálás (International Waterbird Census - IWC) adatbázisába kerülnek, így a nemzetközi adatszolgáltatásnak hazánk eleget tesz.

Mivel a vetési lúd több országot érintő vonuló faj, ezért közös nemzetközi kutatási programok kidolgozásával, tanulmányutak szervezésével a védelmi gyakorlat eredményesebbé tételét lehetne elérni.

Jelentőség: Magas (8-10)

Hatékonyság: Közepes (6)

Ütemezés: Folyamatosan

Felelős: Földművelésügyi Minisztérium, OMVV, OMVK, NymE Vadgazdálkodási és Gerinces Állattani Intézet - Magyar Vízivad Kutató Csoport Sopron, Ramsari Egyezmény Magyar Nemzeti Bizottsága.

\subsubsection{Kutatás és monitoring}

\section{Vonuló- és telelóállományok monitorozása}

Hazánkban a Nyugat-magyarországi Egyetem Vadgazdálkodási és Gerinces Állattani Intézete 1984-től összesen 51 megfigyelési helyen szervezi meg a vízivad, ezen belül a vetési lúd vonuló- és telelőállományának folyamatos monitorozását (FARAGÓ, 1996). A Magyar Vizivad Monitoring hosszú távú fenntartása és támogatása feltétlenül fontos, mert a trendek, folyamatok nyomon követése csak egy ilyen standardizált módszeren alapuló kutatás keretében müködhet megbízhatóan (FARAGÓ, 2008a). A monitoring megfigyelési helyein kívül eső területek adatai is hasznosak lehetnek, föként, ha több éves megbízható adatsorok állnak rendelkezésre. Ebben az esetben vadgazdálkodók, természetvédelmi őrök és civil természetvédelmi szervezetek (pl. MME) is bevonhatók az adatgyüjtésbe.

\section{Predációs nyomás, halandóság vizsgálata}

Az élőhely minősége és a táplálékforrás mellett alapvető fontosságú a predációs nyomás és a túlélési valószínüség ismerete. Különösen fontos az évenkénti szaporulat (felnőtt - fiatal részarány), a költés utáni túlélés eredményességének területenkénti és évenkénti regisztrálása. Ez természetvédelmi szempontból is indokolt, hiszen megfelelő predátor kontrollal a védett madarak fajvédelme is jóval hatékonyabb. A vetési lúd, de más vízivad fajok esetében kísérletes kutatásokkal és automatizált adatgyüjtési módszerekkel (pl. infra vadkamrákkal) lehet vizsgálni.

\section{Vonulás-kutatás}

Az elmúlt években jelentős fejlődés látható a madarak vonulás-kutatásában. A hagyományos fémgyürüs jelölések eredményességét messze felülmúlják a színes gyürüs, a geolokátoros vagy GPS-jeladós vizsgálatok. A korszerü technikákat elsősorban veszélyeztetett fajokon használják, ugyanakkor a gyakori fajokról hazánkban kevésbé állnak rendelkezésre hasonlóan részletes adatok. A módszerek az évek során egyre kedvezőbb áron elérhetők, külföldön (pl. Németország, Hollandia) pedig több évtizedes gyakorlata van. Magyarországon az elmúlt években színes gyürüzési és GPS-jeladós jelöléseket a Fertő-tónál a Fertő-Hanság Nemzeti Park kezdett el. Természetesen érdemes lenne egy programot az egész országra kiterjeszteni, legalább is a föbb élőhelyekre, amivel nemcsak a vonulási útvonal ismerhető meg, hanem a faj élőhelyhasználata, napi aktivitása stb. Utóbbiak az élőhelyfejlesztésben nyújthatnak segítséget. A színes gyürüzés esetén erre fel kell hívni a vadászok, természetvédők és az önkéntes madarászok figyelmét, amivel a leolvasási valószínüséget lehet növelni. 
Az élöhely, az élöhelyfejlesztések és az élöhely-rekonstrukciók hatásának monitorozása

Az élőhelyek állapotának monitorozása, az élőhelyfejlesztések és élőhely-rekonstrukciók hatásának vizsgálata szintén fontos lenne, főként az eredmények értékelés alapján a visszacsatolások révén javítható a beavatkozások hatékonysága, sikere. Mindez nem utolsó sorban anyagi szempontból sem elhanyagolható fontosságú, hiszen fölösleges kiadások is elkerülhetők, illetve kisebb ráfordítással is elérhető ugyanaz a hatékonyság.

\section{A vadászati nyomás vizsgálata}

A vetési lúd vadászat, a vadászati nyomás hatásai jelenleg nem ismertek pontosan, annak ökológiai és ökonómiai alapú elemzése igen hiányos. Ennek megfelelően a folyamatokat is csak empirikus úton, némi után követéssel tudjuk érzékelni, ugyanakkor a hátérben lévő összefüggéseket nem minden részletében látjuk. A vadászati hasznosítás területén olyan módszereket kell bevezetni, megtanulni, amely az eredményes, ám kíméletes vadászatot helyezi előtérbe. Ezek kipróbálása, előzetes elemzése nélkül nem lehet hatékony, fenntartható vízivadgazdálkodást folytatni. A bölcs hasznositás (wise use) gyakorlati alkalmazása az egyedüli járható út a jövőben.

\section{Tájhasználat-változás hatásainak vizsgálata}

A vetési lúd - meglehetősen óvatos faj lévén - a vízivadfajok köréböl az egyik legérzékenyebben reagál bizonyos zavaró hatásokra, a tájhasználat intenzitásának növekedésére. Példaként említhetők egyes kisalföldi táplálkozóterületein megvalósult szélerömü parkok, amelyeknek esetenként markáns eltérítő hatásuk lehet a telelöcentrumok, illetve a táplálkozó területek között kialakult repülési útvonalakra (MUSICZ 2016). Ugyancsak részletesebben vizsgálandók a mezőgazdasági területek kialakult térszerkezetében bekövetkező változások (pl. útépítések, ipari beruházások hatására) és az egyes éjszakázóhelyek viszonylatában fellépő különböző környezeti (főként a gazdálkodásból és üzemeltetésből adódó) hatások.

Jelentőség: Magas (8-10)

Hatékonyság: Közepes (7)

Ütemezés: Folyamatosan

Felelős: Földmủvelésügyi Minisztérium, NymE Vadgazdálkodási és Gerinces Állattani Intézet.

Együttmüködő: vadgazdálkodók, nemzeti parkok, MME

\subsubsection{Kommunikáció és nyilvánosság}

\subsubsection{Kommunikáció az érintett hatóságokkal}

A vetési lúd gazdálkodás hatékonysága érdekében a vadgazdálkodási ágazatnak jó kapcsolatokat kell kialakitani valamennyi, annak sikerességét elösegitö hatósággal:

- megyei vadászati hatóságok,

- FM Erdészeti és Vadgazdálkodási Főosztály,

- NÉBIH,

- területileg illetékes rendőrkapitányságok és ügyészségek,

- vízügyi igazgatóságok,

- zöldhatóságok, nemzeti parkok.

A hatósági szabályzások és az intézkedések előkészítése esetében kívánatos az összes érintett hatóságokkal, kutató intézetekkel, valamint a vadászati és természetvédelmi 
érdekképviseletekkel egyeztetéseket folytatni. Példaként említhetők a vetési lúd egyes kisalföldi táplálkozóterületein elindult szélerőmü-telepítési kezdeményezések, amelyeknek néhány esetben éppen a tömeges vadlúd táplálkozó helyi körülményekre tekintettel nem adott helyt a zöldhatóság.

Jelentőség: Magas (8-10)

Hatékonyság: Jó (8)

Ütemezés: Folyamatosan

Felelős: Földmüvelésügyi Minisztérium

\subsubsection{Kommunikáció a nagyközönséggel}

Kellö rendszerességgel tájékoztatni kell a nagyközönséget, kiemelten a vadászokat és természetvédőket a vetési lúd állományalakulásáról és élöhelye védelmének helyzetéröl. Különösen fontos a nagyközönséggel megismertetni a nyomtatott és elektronikus médián keresztül a vetési lúd egyre csökkenő állományméretét, továbbá az aktuális monitoring és védelmi akciókról tájékoztatást adni. Nagy jelentősége van az érintett vadászterületek településein a helyi sajtón, információs anyagokon, plakátokon keresztüli tájékoztatásnak. Mindez hatékony eszköze a vadászat, vadgazdálkodás társadalmi elfogadottságának és elismertségének. Jó példa a Tatai Öreg-tónál 2001 óta megrendezésre kerülő Tatai Vadlúd Sokadalom, amely civil kezdeményezésre népszerüsíti a tóra érkező vadludakat és folytat átfogó ismeretterjesztő tevékenységet az odaérkező sokezres nézőközönség körében (MUSICZ \& CsonKA 2007, Musicz 2008, 2012, 2014). Szintén Tata vonatkozásában említendő meg az Által-ér völgyi Tanösvény és az Öreg-tó körül kialakított tanösvény, amelyek az itt telelő vadludakról is számos információt nyújtanak a látogatóknak, sőt emblémájukként is a nagy liliket illetve a vetési ludat választották.

Jelentőség: Magas (8)

Hatékonyság: Közepes (6)

Ütemezés: Aktualitások figyelembe vételével, évente ismételve

Felelős: Földművelésügyi Minisztérium, Megyei Kormányhivatalok, OMVV, OMVK, NymE Vadgazdálkodási és Gerinces Állattani Intézet, Magyar Madártani és Természet védelmi Egyesület, Száz Völgy Természetvédelmi Egyesület (és más NGO-k), nemzeti parkok

\subsubsection{Felülvizsgálat}

A Vetési Lúd Kezelési Terv megvalósítását évente áttekinti az Országos Vadgazdálkodási Tanács, és állásfoglalása alapján értékeli az FM Erdészeti és Vadgazdálkodási Főosztálya, amely azután - ha a szükség úgy kívánja - meghozza a szükséges intézkedéseket. Az egyes pontok megvalósulását a visszacsatolások révén folyamatosan figyelni kell.

\section{3. ÖSSZEFOGLALÁS}

\subsection{A VETÉSI LÚD ÁLLOMÁNY ÉS HASZNOSÍTÁS HELYZETE}

A vetési lúd 1950-es években tapasztalható nagyarányú fogyatkozása után, az 1970-es évekre először lassú, majd gyors állománynövekedés következett be, aminek mintegy 43\%-os volt. Az 1980/1981-es idényben bekövetkezett a nagy váltás is, a Magyarországon vonuló és telelő vadludak között a vetési lúd átvette a vezető szerepet. Korábban 10-44\%-nyi részesedése, 
1980/1981-ben már 75\% volt (STERBETZ, 1983). Ezt követően a vetési lúd állománynövekedése a korábbinál is jelentékenyebbé vált, 1984 novemberében 196750 pldnyal tetőzött (FARAGÓ et al., 1991). A legnagyobb tömegek azokban az években a Fertő-tónál, a Balaton Ny-i medencéjében és a Kis-Balatonon, a Tatai Öreg-tónál, a Dinnyési Fertőnél és a Soponyai-halastavaknál vonultak át. Az 1980-as évek közepétől észlelt csökkenése után, a korábbi csúcsmennyiségnek csak fele-harmada jelent meg. Megfogyatkozását részben az enyhe telekre, részben a hosszú száraz periódusra vezettük vissza. Enyhe teleken a tőlünk É-ra fekvő területeken (Németország, Csehország) megrekedt a vonulás. A csapadék hiánya elsősorban az Alföldön eredményezte a vetési lúd visszaszorulását. Az 1990-es évek közepe óta tapasztalható változatlanul alacsony tetőző egyedszámok esetleg a kárpótlásokkal megszünt nagyüzemi kukoricatarlók kínálta táplálékbőség elmaradására vezethetők vissza, bár az ugyanezen táplálékbázisra alapuló nagy lilik állománya mindeközben növekedett. Az utóbbi 15 évben drámai a faj hazai csökkenése, hiszen 2000-től már nem érte el tetőző egyedszáma az 50000 pld-t, 2012-től pedig a 10000 pld-t (FARAGÓ, 1995; FARAGÓ, 1996; 1997a; 1999a; 2010; 2015). A legvalószínübb indok a Pannon-régióban telelő létszám csökkenésére a telelőterület nyugati irányú áthelyeződése lehet.

Faji szintű teríték nyilvántartásáról 1994 óta állnak rendelkezésre adatok. Terítéke az elmúlt 20 esztendőben - hasonlóan a számlált mennyiséghez - jelentős visszaesést mutatott. 1994-ben 6071 pld, 2000-ben 4389 pld, 2005-ben 2681 pld, 2010-ben 3063 pld, 2011-ben 3430 pld, 2012-ben 2100 pld, 2013-ban 1724 pld, 2014-ben 1180 pld volt (CSÁNYI 1996; CSÁNYI 2001; CSÁNYI et al. 2006, 2012a; 2012b, 2012c, 2014).

\subsection{JOGI HELYZET}

A vetési lúd európai állományának védelmi helyzete stabil (S), veszélyeztetettségi státusa (SPEC kategória) alapján kedvező védelmi helyzetü (Non-SPEC) (BIRDLIFE INTERNATIONAL, 2004). A Berni Egyezmény II. Mellékletében, a Bonni Egyezmény II. Függelékében és az EU Madárvédelmi Irányelvek II/1 és III/2. Függelékében szerepel.

A vetési lúd vadászható faj Magyarországon, vadgazdálkodási értéke 20000 Ft. Vadászati idénye október 1.-január 31 között került meghatározásra, naponta, személyenként legfeljebb 6 példány ejthető el.

További megkötés, hogy a vetési lúd vadászati idénye Hajdú-Bihar, Békés és Csongrád megye teljes közigazgatási területén, valamint Jász-Nagykun-Szolnok megye tiszántúli területén december 1-jén kezdődik és január 31-ig tart, amelynek alapvető indoka a globálisan veszélyeztetett vonuló és telelő kis lilikek (Anser erythropus) tévedésen alapuló lelövésének megelőzése volt.

\subsection{VADGAZDÁLKODÁSI PRIORITÁS}

A vetési lúd az egyetlen vadászható lúdfajunk, amelynek állománya az elmúlt 20 évben drámaian csökkent hazánkban. Éves vadászati hasznosítása ma már nem éri el az ezer példányt. Vadgazdálkodási prioritása igen alacsony.

\subsection{CÉLOK}

A rövid és hosszú távú cél a stabil telelő populáció fenntartása, esetlegesen növelése, bár e lehetőség kulcsa nem a magyar vadgazdálkodás kezében van. 


\section{5. ÁTFOGÓ VÉDELMI POLITIKA}

Fontos feladat az jó élőhelystruktúra, a telelő és pihenőhelyek, éjszakázó helyek megőrzése, kímélete. Jelentős szerepe van a táplálékforrásnak, annak minőségének és mennyiségének, ami megfelelő gazdálkodással pozitívan befolyásolható. Az eredményes védelem egyik alapja a nyugalom biztosítása. Mivel a vadászati hasznosítás jelentős nyomást jelent, ezért a vadászterületeken megfelelő időbeli és térbeli korlátozásokat együtt, vagy külön-külön kell alkalmazni. További alapvető kérdés a predációs nyomás mértéke, illetve annak szabályozása. Az állománynövelés hatékony módja az élőhelyfejlesztés, nemcsak meglévő élőhelyek javításával, hanem degradált területeken élöhely-rekonstrukciók végrehajtásával vagy akár új vizes élöhelyek létesítésével. A vetési lúd érdekében elvégzett élöhelyfejlesztés természetesen más vízivad fajok számára is kedvező, ezért nemcsak vadgazdálkodási, hanem természetvédelmi szempontból is kívánatos.

\subsection{CSELEKVÉSI TERV}

\section{1. Élőhelygazdálkodás}

C1.1. A meglévő élőhelyek kímélete, fenntartásuk a leghatékonyabb élőhely-gazdálkodási tevékenység.

Nagy jelentöségü, hatékony. Felelös szervezet: Földmüvelésügyi Minisztérium, megyei vadászati hatóságok.

C1.2. Élőhelyfejlesztés, megfelelő éjszakázó, egyszersmind telelő, továbbá táplálkozó területek kialakítása.

Nagy jelentöségü, hatékony. Felelös szervezet: Földmüvelésügyi Minisztérium, megyei vadászati hatóságok.

C1.3. A dúvad - különösen a róka - gazdálkodást kiemelten kell kezelni, és az éves tervekben rögzíteni kell elöírásait. A hatósági munka során érvényt kell szerezni betartásuknak.

Nagy jelentöségü, hatékony. Felelös szervezet: Földmüvelésügyi Minisztérium, megyei vadászati hatóságok, NymE Vadgazdálkodási és Gerinces Allattani Intézet, Magyar Csapdázók Egyesülete.

\section{Politika és jogalkotás}

C2.1. Szorgalmazni kell a vadászatok során más nem vadászható vízimadárfajok kíméletét, a halgazdálkodók által végzett kárókatona-gyérítések során a vetési lúd és más vízimadárfajok kíméletét.

Nagy jelentöségü, hatékony. Felelös szervezet: Földmüvelésügyi Minisztérium

C2.2. A politikai döntéshozás, a vidékfejlesztési programok és a természetvédelmi stratégiák, koncepciók során előtérbe kell helyezni az élőhelyfejlesztések és a vizes élőhelyek rekonstrukciójának támogatását.

Nagy jelentőségü, hatékony. Felelős szervezet: Földmüvelésügyi Minisztérium

\section{Tanácsadás, oktatás}

C3.1. Rendszeres kapcsolattartás szükséges a földhasználókkal és vadgazdákkal. Meg kell ismertetni a gazdálkodókkal a vetési lúd gazdálkodás helyzetét, a védelem lehetséges módjait, az érintettek közös érdeken alapuló részvételi lehetőségét a védelmi munkában.

Nagy fontosságú, közepes hatékonyságú. Felelös: Földmüvelésügyi Minisztérium, megyei vadászati hatóságok.

C3.2. A vetési lúd gazdálkodásra vonatkozó ismeretek oktatása és az ismeretek folyamatos aktualizálása fontos az alap-, közép- és felsőfokú vadgazdálkodási és természetvédelmi 
szakemberképzésben. A rendszeres továbbképzések során ugyancsak ismertetni kell a fenntartható vetési lúd gazdálkodás célkitüzéseit, módszereit és eredményeit.

Nagy fontosságú, nagy hatékonyságú. Felelős: OMVV, OMVK országos és megyei területi szervezetei, NymE Vadgazdálkodási és Gerinces Állattani Intézet.

\section{Nemzetközi együttmüködés}

C4.1. A Magyar Vízivad Monitoring általi adatszolgáltatás a Wetlands International részére.

C4.2. Részvétel a BirdLife International és a Wetlands International Goose Specialist Group munkacsoport munkájában.

C4.3. Együttmüködés elmélyítése a védelem és kutatás területén a hazai vetési lúd állománnyal érintett országokkal.

Nagy fontosságú, közepes hatékonyságú. Felelös: Földmüvelésügyi Minisztérium, OMVV, OMVK, NymE Vadgazdálkodási és Gerinces Állattani Intézet, Ramsari Egyezmény Magyar Nemzeti Bizottsága.

\section{Kutatás és monitoring}

\section{Vonuló- és telelöállományok monitorozása}

C5.1. Magyar Vízivad Monitoring hosszú távú fenntartása és támogatása.

C5.2. Magyar Vízivad Monitoring megfigyelési helyein kívül eső területek adatainak gyüjtése vadgazdálkodók, természetvédelmi örök és civil természetvédelmi szervezetek bevonásával.

\section{Predációs nyomás, halandóság vizsgálata}

C5.3. A predációs nyomás és a túlélési valószínüség vizsgálata kísérletes kutatásokkal és automatizált adatgyüjtési módszerekkel.

\section{Vonuláskutatás}

C5.4. Országos színes-gyürüzési (lábgyürü, nyakgyürü) program elindítása.

C5.5. A fontosabb hazai telelőhelyeken fogott egyedek GPS-jeladóval való vonulási útvonal, élőhelyhasználat és napi aktivitás vizsgálata.

Az élőhely, az élőhelyfejlesztések és az élőhely-rekonstrukciók hatásának monitorozása

C5.6. Az élőhelyek állapotának monitorozása, az élőhelyfejlesztések és élőhelyrekonstrukciók hatásának vizsgálata.

A vadászati nyomás vizsgálata

C5.7. A vetési lúd vadászati hasznosítás mértékének vizsgálata, az állomány- és terítékadatok együttes elemzése.

\section{Tájhasználat-változás hatásainak vizsgálata}

C5.8. Elsősorban a táplálkozó területként jelentős mezőgazdasági területek vonatkozásában jelentkező antropogén hatások vizsgálata

\section{Kommunikáció és nyilvánosság}

A6.1. A vetési lúd gazdálkodás hatékonysága és elfogadtatása érdekében a vadgazdálkodásnak jó kapcsolatokat kell kialakítani valamennyi hatósággal.

Nagy jelentöségü, nagy hatékonyságú. Felelős: Földmüvelésügyi Minisztérium

A6.2. Kellő rendszerességgel tájékoztatni kell a nagyközönséget a vetési lúd állománya és élőhelye védelmi, gazdálkodási helyzetéről.

Nagy fontosságú, közepes hatékonyságú. Felelös: Földmüvelésügyi Minisztérium, Megyei Kormányhivatalok, OMVV, OMVK, NymE Vadgazdálkodási és Gerinces Állattani Intézet, Tatai Vadlúd Sokadalom szervezöi.

\section{Felülvizsgálat}

A Vetési lúd Kezelési Terv megvalósítását évente áttekinti az Országos Vadgazdálkodási Tanács, és állásfoglalása alapján értékeli az FM Erdészeti és Vadgazdálkodási Főosztálya, amely azután - ha a szükség úgy kívánja - meghozza a szükséges intézkedéseket. 


\section{FELHASZNÁLT IRODALOM}

Andrews, J. \& Kinsman, D. (1990): Gravel Pit Restoration for Wildlife: A Practical Manual. Royal Society for the Protection of Birds.

BAUER, K. M. \& GLUTZ von Blotzheim, U.N. (1990): Handbuch der Vögel Mitteleuropas. Band 2. Anseriformes. (1. Teil), Aula-Verlag, Wiesbaden, 2., durchgesehene Auflage. $534 \mathrm{p}$.

van den BERG, L. (1999): Tundra Bean Goose Anser fabalis rossicus. In: MADSEN, J., Cracknell, G. \& Fox, A.D. (szerk.): Goose populations of the Western Palearctic. A review of status and distribution. Wetlands International Publ. No. 48., Wetlands International Wageningen, The Netherlands. National Environmental Research Institute, Rönde, Denmark. pp. 38-66.

BuRgers, J. (1990): Status of Bean Goose populations wintering in Western Europe. IWRB Goose Research Group Newsletter 3: 11-12.

CRAMP, S. \& Simmons, K. E. L. (eds.) (1977): Handbook of the birds of Europe, the Middle East and North Africa. The birds of the Western Palearctic. Volume I. Ostrich to ducks. Oxford University Press, Oxford.

CSÁNYI S. (szerk.) (1996): Vadgazdálkodási Adattár - 1960-1995. Országos Vadgazdálkodási Adattár, Gödöllö. o. sz. n.

CsÁNYi S. (szerk.) (2001): Vadgazdálkodási Adattár - 2000/2001 vadászati év. Országos Vadgazdálkodási Adattár, Gödöllő. o. sz. n.

CsÁNYI S. (szerk.) (2002): Vadgazdálkodási Adattár - 2001/2002 vadászati év. Országos Vadgazdálkodási Adattár, Gödöllö. o. sz. n.

CSÁNYI S. (2015)(szerk.): A 2014/2015. vadászati év vadgazdálkodási eredményei valamint a 2015. tavaszi vadállomány-becslési adatok és vadgazdálkodási tervek. Országos Vadgazdálkodási Adattár, Gödöllö. 152 p.

CSÁNYi S., LeHOCZKY R. \& SONKOly K. (szerk.) (2006): Vadgazdálkodási Adattár 2005/2006. vadászati év. Országos Vadgazdálkodási Adattár, Gödöllő. 64 p.

CsÁNYi S., LEHOCZKY R. \& SONKOly K. (szerk.) (2010): Vadgazdálkodási Adattár 2009/2010. vadászati év. Országos Vadgazdálkodási Adattár, Gödöllő. 56 p.

CSÁNYI S., LEHOCZKY R. \& SONKOLY K. (szerk.) (2012a): Vadgazdálkodási Adattár 2010/2011. vadászati év. Országos Vadgazdálkodási Adattár, Gödöllő. 52 p.

CsÁNYi S., LEHOCZKY R. \& SONKOLY K. (szerk.) (2012b): Vadgazdálkodási Adattár 2011/2012. vadászati év. Országos Vadgazdálkodási Adattár, Gödöllö. 52 p.

CsÁNyi S., Tóth K. \& Schally G. (szerk.) (2012c): Vadgazdálkodási Adattár - 2012/2013. vadászati év. Országos Vadgazdálkodási Adattár, Gödöllő. 52 p.

CsÁNyi S., Tóth K., KovÁCs I. \& Schally G. (szerk.) (2014): Vadgazdálkodási Adattár 2013/2014. vadászati év. Országos Vadgazdálkodási Adattár, Gödöllő. 48 p.

FARAGÓ S. (1994): Habitat use and daily activity and feeding of the geese of Lake Fertő. Aquila 101: $65-88$.

FARAGÓ, S. (1995): Geese in Hungary 1986-1991. Numbers, migration and hunting bags. IWRB Special Publications 36.97 p.

FARAGÓ S. (1996): A Magyar Vadlúd Adatbázis 1984-1995: Egy tartamos monitoring. - Data base of geese in Hungary 1984-1995: A long-term monitoring. Magyar Vizivad Közlemények 2: 3-168.

FARAGÓ S. (1997a): A vadlúd monitoring eredményei az 1996/1997-es idényben Magyarországon. Magyar Vízivad Közlemények 4: 17-60.

FARAGÓ S. (1997b): Élőhelyfejlesztés az apróvad-gazdálkodásban. A fenntartható apróvadgazdálkodás környezeti alapjai. Mezőgazda Kiadó, Budapest. 
FARAGÓ S. (1999): A vadlúd monitoring eredményei az 1997/1998-as idényben Magyarországon. Magyar Vízivad Közlemények 5: 3-62.

FARAGÓ S. (2000): A vadászható vízivad fajok magyarországi vonulása, jelölt madarak megkerülése alapján. Magyar Vizivad Közlemények 6: 337-375.

FARAGÓ S. (2001): A vadlúd monitoring eredményei az 1998/1999-es idényben Magyarországon. Magyar Vízivad Közlemények 7: 3-40.

FARAGÓ S. (2002a): A vadlúd monitoring eredményei az 1999/2000-es idényben Magyarországon. Magyar Vízivad Közlemények 8: 3-43.

FARAGÓ S. (2002b): A vadlúd monitoring eredményei a 2000/2001-es idényben Magyarországon. Magyar Vizivad Közlemények 9: 3-45.

FARAGÓ S. (2002c): Vadászati állattan. Mezőgazda Kiadó, Budapest, 496 p.

FARAGÓ S. (2005): A vadlúd monitoring eredményei a 2002/2003-as idényben Magyarországon. Magyar Vizivad Közlemények 12: 3-42.

FARAGÓ S. (2006a): A vadlúd monitoring eredményei a 2003/2004-es idényben Magyarországon. Magyar Vizivad Közlemények 13: 3-39.

FARAGÓ S. (2006b): A vonuló vizivad populációk fenntartásának alapjai Magyarországon. MTA doktora értekezés, MTA, Budapest. 500+305 p.

FARAGÓ S. (2007a): A vadlúd monitoring eredményei a 2004/2005-ös idényben Magyarországon. Magyar Vízivad Közlemények 14: 3-40.

FARAGÓ S. (2007b): A vadlúd monitoring eredményei a 2005/2006-os idényben Magyarországon. Magyar Vizivad Közlemények 15: 3-45.

FARAGÓ S. (2008a): A Magyar Vízivad Monitoring standardizált megfigyelési területei. Magyar Vizivad Közlemények 16: 21-48.

FARAGÓ S. (2008b): A vadlúd monitoring eredményei a 2006/2007-es idényben Magyarországon. Magyar Vizivad Közlemények 17: 3-42.

FARAGÓ S. (2010a): A vadlúd monitoring eredményei a 2007/2008-as idényben Magyarországon. Magyar Vízivad Közlemények 18-19: 3-41.

FARAGÓ S. (2010b): A vadlúd monitoring eredményei a 2008/2009-es idényben Magyarországon. Magyar Vízivad Közlemények 18-19: 221-258.

FARAGÓ S. (2011a): A vadlúd monitoring eredményei a 2009/2010-es idényben Magyarországon. Magyar Vízivad Közlemények 20-21: 3-42.

FARAGÓ S. (2011b): A vadlúd monitoring eredményei a 2010/2011-es idényben Magyarországon. Magyar Vizivad Közlemények 20-21: 201-250.

FARAGÓ S. (2011c): Habitat selection of migratory waterfowl species in Hungary. Aquila 118: 7-26.

FARAGÓ S. (2012): A vadlúd monitoring eredményei a 2011/2012-es idényben Magyarországon. Magyar Vizivad Közlemények 22: 3-50.

FARAGÓ S. (2014): A vadlúd monitoring eredményei a 2012/2013-es idényben Magyarországon. Magyar Vizivad Közlemények 24: 3-49.

FARAGÓ S. (2015): A vadlúd monitoring eredményei a 2013/2014-es idényben Magyarországon. Magyar Vizivad Közlemények 25: 1-54. http://dx.doi.org/10.17242/MVvK_Monitoring/25-1

FARAGÓ S. (2016): A vadlúd monitoring eredményei a 2014/2015-ös idényben Magyarországon. Magyar Vizivad Közlemények 27: 3-53. http://dx.doi.org/10.17242/MVvK_27.01

FARAGÓ S. \& GOSZTONYI L. (2003): A vadlúd monitoring eredményei a 2001/2002-es idényben Magyarországon. Magyar Vízivad Közlemények 11: 3-50.

FARAGÓ S. \& JÁNOSKA F. (1996): A vadlúd monitoring eredményei az 1995/1996-os idényben Magyarországon. Magyar Vízivad Közlemények 2: 169-212. 
FARAGÓ, S., KovÁcs, G. \& SterbetZ, I. (1991): Goose populations staging and wintering in Hungary 1984-1988. Ardea 79: 161-163.

FAragó S. \& Pellinger A. (2009): Vetési lúd. In: CsÖrgö, T., KARCZA, Zs., Halmos, G., Magyar, G. Gyurácz, J., Szép, T., Bankovics, A., Schmidt, A. \& Schmidt E. (szerk.): Magyar madárvonulási atlasz. Kossuth kiadó. pp.112-114.

FARKAS T. (2009): Csapdázásra alapozott ragadozógazdálkodás. Vadgazda mérnöki szakdolgozat, SZIE MKK VMI., Gödöllö. 56 p.

FÖLDMÜVELÉSÜGYI MINISZTÉRIUM (2015): Ramsari Egyezmény - Ramsari területek Magyarországon. http://www.termeszetvedelem.hu/ramsari-egyezmeny

HAJAs P. P. (2011): Rókacsapdázási módszerek összehasonlítása. In: LAKATOS F., POLGÁR A. \& KerÉNYI-NAgY V. (szerk.): Tudományos Doktorandusz Konferencia - Konferenciakötet. Nyugat-magyarországi Egyetem Kiadó, Sopron. p. 230-232.

HAJAS P. P. (2012): Visszatartó kábeles csapdák. Jó vadászatot 2: 19-20.

HAJAS P. P. (2013): Comparision of traditional jaw type killing traps and modern cable restraints to capture foxes. In: IUGB: Programme \& Abstract Book: 31st IUGB Congress p. 182.

HARRISON, C. (1975): Jungvögel, Eier und Nester aller Vögel Europas, Nordafrikas und des Mittleren Ostens. Verlag Paul Parey, Hamburg und Berlin.

Heltai M. (szerk.) (2010): Emlős ragadozók Magyarországon. Mezőgazda Kiadó, Budapest. $240 \mathrm{p}$.

Heltai M. \& Szemethy L. (2000): A vadgazdálkodás törvényes lehetőségei a ragadozókkal való együttélésben. A Vadgazdálkodás Időszerü Tudományos Kérdései 1: 89-98.

HuYsKens, P. R. G. (1986): The Bean Goose problem in Europe. Oriolus 52: 105-256.

HuYsKens, G. (1999): The Taiga Bean Goose (Anser fabalis): a species that needs worldwide protection. Kapellen, The Netherlands. $64+13 \mathrm{p}$.

JohAnsen, H. (1962): A Magyarországon telelő vetési ludak. Aquila 67-68: 33-38.

Jonsson, L. (1993): Birds of Europe with North-Africa and Middle East. C. Helm Publisher Ltd/A. \& C. Black Publisher Ltd. London

KALBE, L. (1981): Ökologie der Wasservögel. Neue Brehm Bücherei 518. 2. Auflage, A. Ziemsen Verlag. Wittenberg-Lutherstadt, $116 \mathrm{p}$.

KalotÁs Zs. (1992): Átnyaraló vetési ludak (Anser fabalis). Madártani Tájékoztató 1992. Jan.-jún.: 25.

KeVE, A. (1984): Magyarország madarainak névjegyzéke. Nomenclator avium Hungariae. Biológiai Tanulmányok 11., Akadémiai Kiadó, Budapest. 100 p.

LANSZKI J. (2002): Magyarországon élő ragadozó emlősök táplálkozás-ökológiája. Natura Somogyiensis 4: $177 \mathrm{p}$.

LANSZKI J. (2012): Ragadozó emlösök táplálkozási kapcsolatai. Natura Somogyiensis 21: 310 p.

Lotz Gy. 1988: A Kis-Balaton vízvédelmi rendszer. Hidrológiai Tájékoztató 28(2): 20-22.

Madsen, J., Cracknell, G. \& Fox, T. (szerk. 1999): Goose populations of the Western Palearctic. A review of status and distribution. Wetlands International Publication 48. Wetlands International Wageningen, The Netherlands. National Environmental Research Institute, Rönde, Denmark. 344 p.

Magyar,G., Hadarics, T., Waliczky, Z., Schmidt, A. \& Bankovics, A. (1998): Nomenclator Avium Hungariae. Magyarország madarainak névjegyzéke. Madártani Intézet - MME- Winter Fair. Budapest-Szeged. 202 p.

Magyarics A., Pomogyi P. \& PÉK T. (1999): A Kis-Balaton védőrendszerének kialakítása, müködésének eredményei. Vizügyi Közlemények 81(4): 615-646.

Makatsch, W. (1974): Die Eier der Vögel Europas. Band 1. Neumann Verlag, Radebeul. $467 \mathrm{p}$. 
MME NOMENClATOR BIZOTTSÁG (2008): Magyarország madarainak névjegyzéke. Nomenclator avium Hungariae. Magyar Madártani és Természetvédelmi Egyesület, Budapest. $278 \mathrm{p}$.

Musicz L. (2008): Tata madártani jelentőségének áttekintése. In: FüLÖP É. (szerk.) Komárom-Esztergom Megyei Múzeumok Közleményei 13-14: 383-397.

Musicz L. (2012): Vadludak, vízimadarak Tatán. In: Tatai Patrióta 3., Vizek és Vadludak. Móricz Zsigmond Városi Könyvtár, Tata. pp. 40-54.

Musicz, L. (2014): Vadlúd monitoring a Tatai-tavakon. Monitoring of wild geese on the Lakes of Tata. Szélkiáltó 16: 17-19.

Musicz, L. (2016): Összefoglaló jelentés a nagyigmándi szélerőmüpark madártani vizsgálatáról. Kézirat, 33 p.

Musicz L. \& CsOnKA P. (2007): Tatai tavak (A tatai Öreg-tó, a Ferencmajori- és a Rétihalastavak). In: TARDY J. (szerk.): A magyarországi vadvizek világa. Hazánk Ramsari területei. Alexandra Könyvkiadó. Pécs. pp. 62-77.

NAGY Sz. \& KÖNCZEY R. (szerk.)(1995): Természetvédelem a halastavakon. IUCN Magyarországi Alapítvány és MME kiadványa, Budapest, 58 p.

Rose, P.M. \& ScotT, D.A. (1997): Waterfowl Population Estimates. Second Edition. Wetlands International Publication 44. 106 p.

RutschKe, E. (1987): Die Wildgänse Europas. Biologie, Ökologie und Verhalten. VEB Deutscher Landwirtschaftsverlag, Berlin. 255 p.

RutschKe, E. (1997): Wildgänse. Lebensweise, Schutz, Nutzung. Parey Buchverlag, Berlin.

SANGSTER, G. \& OREel, G.J. (1996): Progress in taxonomy of Taiga and Tundra Bean Geese. Dutch Birding 18: 310-316.

Sangster, G., Hazevoet, C.J., VAn Den Berg, A.B. RoselaAr, C.S. \& Sluys, R. (1999): Dutch avifaunal list: Species concepts, taxonomic instability and taxonomic changes in 1977-1998. Ardea 87: 139-165.

Scott, D. A. \& Rose, P. M. (1996): Atlas of Anatidae Populations in Africa and Western Eurasia. Wetlands International Publication, 41., Wetlands International, Wageningen, The Netherlands, $336 \mathrm{p}$.

Standovár T. \& Primack, R. B. (2001): A természetvédelmi biológia alapjai. Nemzeti Tankönyvkiadó, Budapest.

STERBETZ, I. (1979): A nagy lilik (Anser albifrons), a kis lilik (Anser erythropus) és a vetési lúd (Anser fabalis) táplálkozási viszonyai Magyarországon. Aquila 85: 93-106.

STERBETZ I. (1981): Megfigyelések a Sushkin lúd (Anser $f$. neglectus) etológiájáról és ökológiájáról. Hajdúsági Múzeum Évkönyve 4: 31-44.

STERBETZ, I. (1983): A magyarországi vadlúdvonulás alakulása az 1972 és 1982 közötti időszakban. Állattani Közlemények 70: 69-72.

TARDY J., MARGÓCZI K. \& TAKÁCS A. (2007): Megvalósult vizesélöhely-rekonstrukciók Magyarországon. In: Tardy J. (szerk.): A magyarországi vadvizek világa. Hazánk ramsari területei. Alexandra Kiadó. p. 24-25.

TUCKer, G. M. \& Evans, M. I. (1997): Habitat for Bird in Europe: A Conservation Strategy for the Wider Environment. BirdLife Conservation Series 6.

WetLands InTERNATIONAL (2015): Waterbird Population Estimates. Wetlands International Wageningen, The Netherland, - Online data base.

KSH STADAT http://www.ksh.hu/docs/hun/xstadat/xstadat_eves/i_omf001b.html 


\title{
MANAGEMENT PLAN FOR BEAN GOOSE (Anser fabalis) IN HUNGARY
}

\author{
Faragó, S., Musicz, L. \& Hajas, P. P.
}

\section{SUMMARY}

The management plan for Bean Goose (Anser fabalis) was made in the following structure:

\section{Biology and ecology of Bean Goose, evaluation of conservation praxis}

1.1.Introduction

1.2.Ecology

1.2.1. Habitat conditions

1.2.2. Reproduction

1.2.3. Feeding

1.3.Distribution

1.4. Movement and wintering

1.5. Population size

1.6.Danger and limiting factors

1.6.1. Primer parameters determinant of population density

1.6.2. Ecological factors determinant of population density

1.6.3. Summary of threatening factors of Bean Goose

1.7. Evaluation/appreciation of conservation practice

1.7.1. Habitat conservation and management

1.7.2. Conservation of wild populations

\section{Action plan}

2.1.Objectives

2.2.Tasks

2.2.1. Enlargement of populations on the basis of wild populations

2.2.2. Habitat management

2.2.2.1. Protection of existing habitats

2.2.2.2. Habitat improvement

2.2.2.3. Predator management

2.2.3. Policy and legislation

2.2.4. Advising for landowners and game managers

2.2.5. Education and advanced studies

2.2.6. International cooperation

2.2.7. Research and monitoring

2.2.8. Communication and publicity

2.2.8.1. Communication with the competent authorities

2.2.8.2. Communication with the collectivity

2.2.9. Revision

\section{Summary}


